\title{
Mallotus philippensis (Lam.) Müll. Arg.: comprehensive review on ethnomedicinal uses
}

Abhishek Kumar ${ }^{1}$, Meenu Patil ${ }^{1}$, Pardeep Kumar ${ }^{1}$, Ram Chand Bhatti ${ }^{1}$, Rupinder Kaur ${ }^{1}$, Nitin Kumar Sharma ${ }^{2}$ and Anand Narain Singh ${ }^{1 *}$

\begin{abstract}
Despite advances in biomedical technology, many communities and local people are still dependent on natural and herbal medications. A large number of different ethnic groups like the Tharu, Kani, Garo and other local inhabitants thrive in the Indian subcontinent and other parts of the world. These indigenous people traditionally use Mallotus philippensis (Lam.) Müll. Arg. (Euphorbiaceae) for a variety of medicinal (ethno-veterinary and ethno-medicines), ritual and economic purposes. Therefore, the present article aims to assess how many various types of disorders are being treated by the ethnic groups using formulations prepared from this tree. In addition, we aim to identify the gaps in knowledge and recommend future investigations based upon them. The present analysis based on 83 articles indicated that different ethnic groups are utilising the tree to treat about 142 health ailments that can be broadly categorised into 11 types of disorders. Among these disorder categories, helminthic infestations, dermatological and digestive disorders are most frequently treated with formulations prepared from this tree. Among plant parts, fruits are the most exclusively used component followed by leaves and bark. The usage of fruits as an anthelminthic is widespread and highly cited for both animals and human beings. Thus, the tree can serve as a promising ethnomedicine to treat helminthic infestations, dermatological and digestive problems. Therefore, the cultivation of this medicinal plant should be encouraged in order to promote the conservation of this species.
\end{abstract}

Keywords: Kamala Tree; Mallotus philippensis; Medicinal Uses; Traditional Uses.

\footnotetext{
1 Department of Botany, Panjab University, Chandigarh, 160014, India.

2 Department of Botany, Maharana Pratap Govt. College Amb, Una, HP, 177203, India.

*Corresponding author. \E-mail address: AK (abhikumar.pu@gmail.com; abhikumar8@pu.ac.in), MP (patilmeenu2@gmail.com; patilmeenu@pu.ac.in), PK (pardeepmor989@gmail.com), RCB (hnarambhatti@gmail.com), RK (rupinderkaurrupy@yahoo.com), NKS (nitinbot@gmail.com), ANS* (ansingh@pu.ac.in; dranand1212@gmail.com)
}

\section{SIGNIFICANCE STATEMENT}

We analyzed the medicinal uses of the Kamala tree (Mallotus philippensis) among the ethnic groups of the Indian subcontinent. We found that the fruits of this tree are most frequently used for treating the helminthic infestations and skin disorders. This suggests that the fruits may have some active bio-chemicals that can be exploited for drug development. Further, relatively smaller number of studies as compared to ethnic diversity point towards a scope of further exploration of traditional uses of this particular tree. Future studies should investigate medical efficacy of active bio-chemical compounds isolated from the tree. 


\section{INTRODUCTION}

Mallotus philippensis (Lam.) Müll. Arg. (Kamala tree), a member of Euphorbiaceae, is a perennial small to medium-sized tree, reaching more than $20 \mathrm{~m}$ in height. The medicinal potential of this tree finds frequent mention in ancient Indian literature like Charaka Samhita, Sushruta Samhita which is based on Ayurvedic system of medicines, Indian Materia Medica of Indian origin and Indusyunic Medicine in Pakistan (Khare 2007; Nadkarni 1976; Usmanghani et al. 1997). Indusyunic Medicine is a medicinal system evolved from ancient Unani and Ayurvedic system of medicines that also practice some newly adopted herbal drug formulations in Pakistan and adjacent regions (Usmanghani et al. 1997). According to Ayurveda, the fruits and leaves of this plant have anthelminthic, appetising, bitter, carminative, cooling, purgative and vulnerary properties (Ahmad et al. 2009; Gupta 2015). The plant is also said to be useful for bladder-stones, abdominal diseases, spleen enlargement, bronchitis, ulcers and tumours (Kirtikar and Basu 1935). Similarly, the Yunani medicinal system states that the red powder obtained from glands and hairs of the fruit have anthelmintic, bitter and styptic properties. It is also speculated to be useful for intestinal pain and skin diseases like scabies, ringworm and other skin disorders (Kirtikar and Basu 1935). Moreover, the powder is thought to stop bleeding, lower the blood glucose and relieve spasm (Khare 2007; Usmanghani et al. 1997). These documented medicinal properties have been scientifically tested and authenticated (Gangwar et al. 2014b; Rivière et al. 2010). A variety of important compounds such as cardenolides, flavonoids, tannins, fatty acids, chalcone and phloroglucinol derivatives have been isolated from this tree (Rivière et al.
2010). These active chemicals have found to possess interesting pharmacological activities like anti-cancer, anthelmintic, antifertility, antimicrobial and anti-inflammatory activity, which support the traditional medicinal uses of this particular tree (Gangwar et al. 2014b).

The medicinal properties of this species are implicated for various drug formulations that are available commercially. For example, the anthelmintic property makes fruit powder an essential constituent for Ayurvedic formulations like Krimighatni Bati and Krimikuthar Rasa that are important drugs used as anthelmintic. Similarly, Roghan Kameela and Zimad Jarb are the important drugs of Unani medicinal system, which are recommended for skin problems (Haque et al. 2015). In addition to these, Itrifal Qanbil, Safuf Hikkah, Itrifal Deedan, Safuf Barg Hina Wala, Qurs Deedan and Marham Kharish Jadid are some of the drug preparations of the Indusyunic Medicines in Pakistan that involve Kamala as one of the active ingredients (Usmanghani et al. 1997). Therefore, the tree is in high demand and quantities (0.155 tonnes/annum) are still required to meet requirements as per the Planning Commission, Government of India (Kala et al. 2006). Hence, the issue of its conservation also arises as to the demand increases.

A large number of people belonging to different ethnic groups and geographical areas still practice the traditional utilisation of this plant as an ethnomedicine for the treatment of health disorders. Various formulations prepared from this tree have been put into use for the treatment of stomach disorders, diarrhoea and dysentery, bronchitis, abdominal diseases, jaundice, urinary complications, parasitic affections and several other health disorders (Ahmad et al. 2009; Ahmed et al. 2017; Barkatullah 
et al. 2015; Ghimire and Bastakoti 2009; Mahato and Chaudhary 2005; Nayak et al. 2004; Panda 2014; Uprety et al. 2011; Verma and Chauhan 2007). However, the pattern and frequency of treating various disorders and health ailments with formulations from this tree are not clear. Although the medicinal uses of this tree are prevalent in the Indian subcontinent and adjacent areas, these traditional uses have not been highlighted in previous review articles (Dhaker and Sharma 2014; Gangwar et al. 2014b; Sharma and Varma 2011; Tripathi et al. 2017). Therefore, in this review, we aim to answer the following questions: (1) How many disorders are being treated by formulations prepared from this tree? (2) Do these formulations vary within or between ethnic groups? (3) Which disorders are most frequently treated by this tree? (4) Among plant parts, which is most commonly used for the treatment of various health disorders? To accomplish this, we have surveyed the available databases along with unpublished grey literature including dissertations and theses. Yet, we do not pretend to be complete in our review, as collecting all the literature is a difficult task and some studies seemed to be beyond the scope of the present review, but surely, it will be useful for future research on the same tree.

\section{General Botanical Information}

The plant is known with more than 100 common names that vary with the geographical area, language and the medicinal system. These non-scientific medicinal names can be accessed at Royal Botanical Garden, Kew: Medicinal Plant Names Services. Botanically, Müller Argoviensis (Müller 1865) described the species as 'Mallotus philippinensis (Lam.)
Müll. Arg.' despite the original basionym epithet being cited as 'Croton philippensis' by Lamarck and Poiret (Lamarck and Poiret 1786). However, the article 60 of the 'International Code of Nomenclature for algae, fungi, and plants' (Turland et al. 2018), states that the original spelling of a taxon must be retained and any typographical or orthographical error should be corrected. Therefore, we strongly recommend the use of corrected specific epithet as "philippensis" instead of "philippinensis". Hence, we have retained the spelling as "philippensis" throughout the article and not "philippinensis" as used by many authors (Ahmed and Siddiqa 2013; Bandopadhyay et al. 1972; Gangwar et al. 2011, 2014a; Jabbar et al. 2006; Kulkarni et al. 2014; Lounasmaa et al. 1975; Panda 2014; Roberts et al. 1963; Saijo et al. 1989). Although the use of most of the synonyms has been substantially diminished in the modern literature, more than 20 botanical synonyms exist in taxonomic literature, which can be accessed at The Plant List.

The tree is morphologically distinguished by opposite granulose-glandular leaves with extrafloral nectaries on the upper surface. Inflorescences are usually terminal and fruits are trilobed dehiscent capsules. Fruits bear red coloured glandular hairs yielding a red powder known as 'Kamala' (Sierra et al. 2005) (Figure 1).

Kamala tree is widely distributed from Pakistan to South China and South Japan, throughout tropical Southeast Asia (Afghanistan, Bhutan, Cambodia, Indonesia, Sri Lanka, Thailand, Singapore and Myanmar) and Malaysia to East Australia and West Pacific (Solomon Islands) and the Philippines (Daikonya et al. 2004; Sierra et al. 2005). This tree is a common member in Sal (Shorea robusta Gaertn. f.), shrub and mixed forests throughout the tropical region 


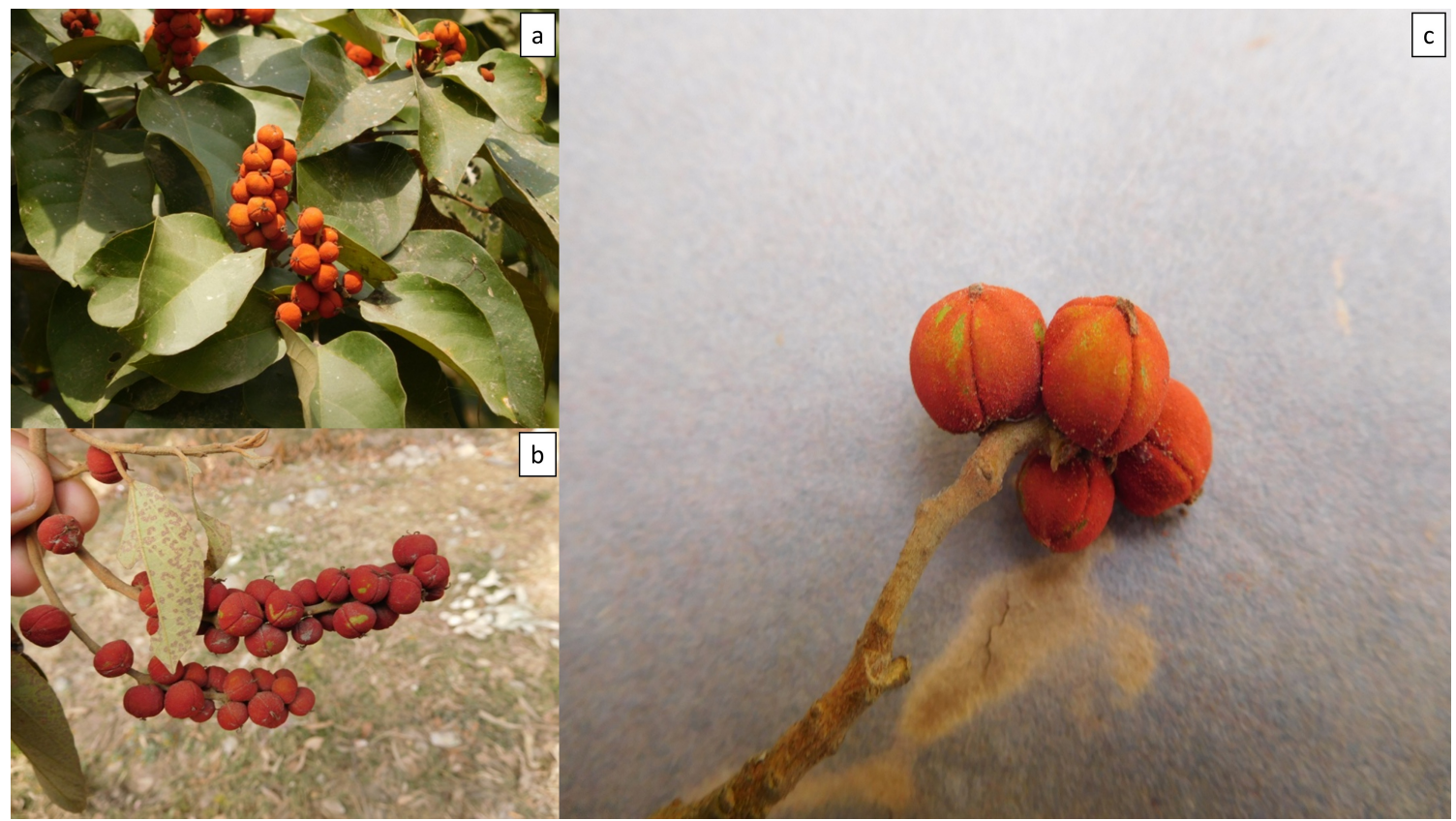

Figure 1. Morphological features of Mallotus philippensis tree (a) a twig with ovate leaves, (b) terminal inflorescence ripened into fruits and, (c) tri-locular fruits (capsules) bearing red glandular hairs.

of India but abundantly distributed in the forests of the Siwalik range of outer Himalayas (Figure 2). It is widespread in the districts of Himachal Pradesh but also occasionally in the drier parts such as Rajasthan, Madhya Pradesh and Uttar Pradesh and peninsular region of India (Khare 2007; Siva 2007).

The habitat of the tree includes scrubby vegetations, open rocky ground and understorey of primary to secondary forests. It is growing well on various sites like disturbed sites, ridges, forest edges, steep slopes, road and riversides. It can manage to grow on variable soil types, like granite, limestone, sandstone, sandy clay, sandy loam soil, gravel and rock (Sierra et al. 2005).

\section{METHODS}

In order to get comprehensive information on this species, we have extensively explored available databases like Scopus (Mallotus AND phili*), Web of Science (Mallotus AND phili*), Google Scholar (allintitle: "Mallotus philippensis" OR "Mallotus philippinensis"), ScienceDirect ("Mallotus philippensis" OR "Mallotus philippinensis"), PubMed (Mallotus AND phili*). We got 245 articles from Scopus, 115 articles from Web of Science, 131 articles from Google Scholar, 313 articles from ScienceDirect, 54 articles from PubMed. Thus, in total, we got 858 articles through database searching and 19 additional records were found through other sources including published books, unpublished theses and dissertations. However, to maximize uniqueness in the collected information, all duplicate articles were discarded and only those articles were selected which described at least one traditional or local medicinal use. Thus, after discarding the duplicate, non-relevant and insignificant studies from the collected articles, finally, 83 articles were used for data extraction and analysis, which were related to ethnobiology or traditional knowledge (see Add File 1). Further, some studies have only included the medicinal use without citing the 


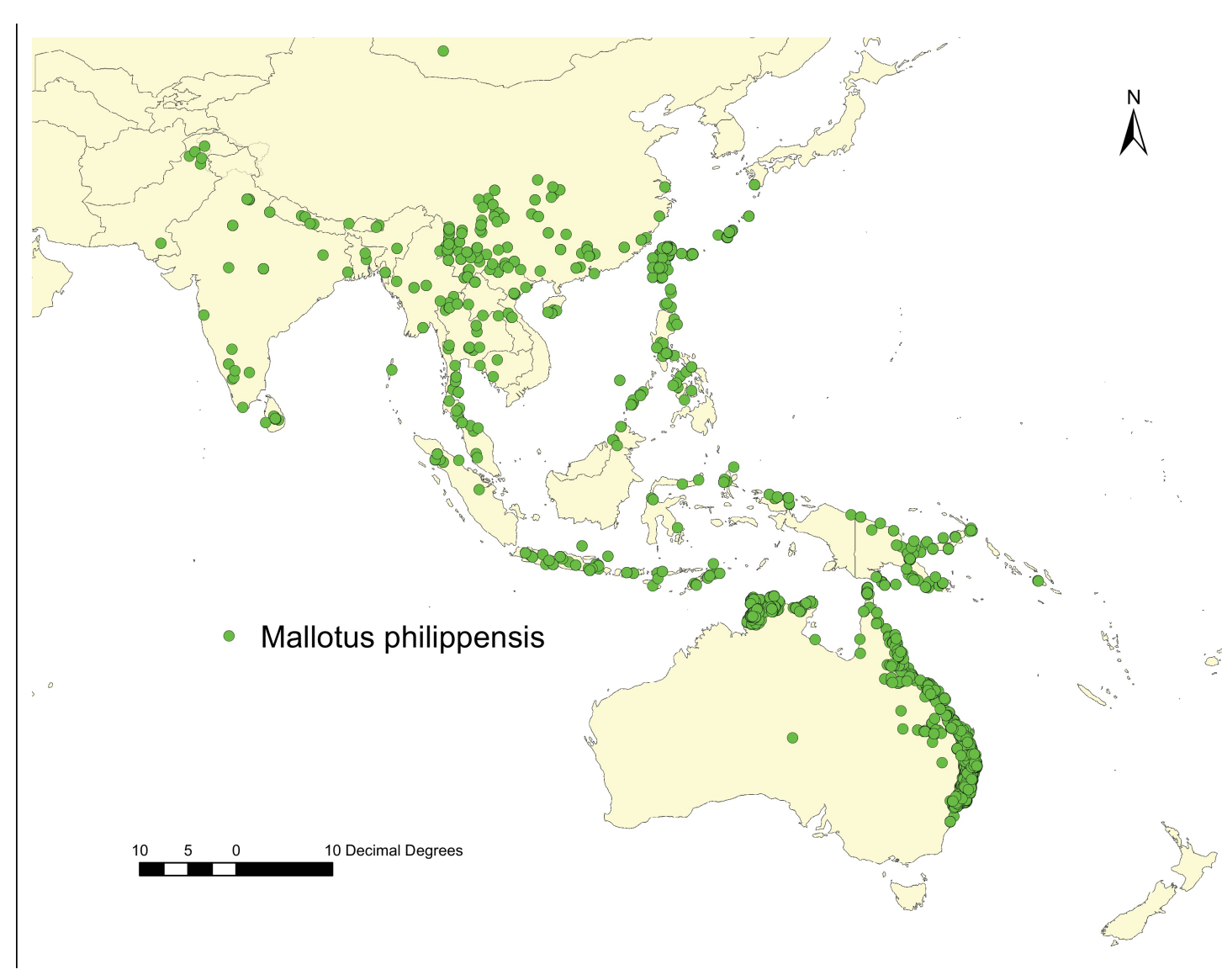

Figure 2. The distribution map of Mallotus philippensis species depicts the predominant distribution from Pakistan to Australia. The distribution data of species was taken from the Global Biodiversity Information Facility (GBIF) (https://www.gbif.org/species/5378605).

proper dosage and formulations, the more than one body system. For inclusion of such studies have been quantification and assessing the consensus discouraged while preparing the manuscript. of the traditional medicinal uses, we Most of these studies were reported from the considered the actual number of informants Indian subcontinent (comprising of India, that cited a particular use in a particular Pakistan, Nepal, Bhutan, Bangladesh and Sri Lanka). Among these selected studies only about 35 studies have deposited a herbarium specimen of the species as indicated by voucher numbers. We have specifically looked for the plant part used, specific formulation and dosage used to treat different diseases (see Add File 1). After acquiring all the information from the articles, the diseases were classified primarily depending on the type of body system affected. However, some diseases were classified based on the source of infection because these diseases tended to affect study. Unfortunately, some studies have not provided the actual number of informants and for such studies, we have considered the number of informants as one. A vote count approach was chosen to assess the consensus of the medicinal use of this tree. The data was compiled using MS Excel and $\mathrm{R}$ programming language ( $\mathrm{R}$ Core Team 2018) was used for graphical representation as figures. 


\section{Socio-Economic Importance}

Natural dyes play an important role in the livelihood of local and rural people. For example, in Bhutan, rural people cultivate dye-yielding plants, prepare dye and earn money by selling the dye (Tshering 1996). The glands of ripened fruits of this tree yield a yellow to orange-red coloured dye, called as the Kamala dye (Panda et al. 2018; Rao and Seshadri 1947; Sierra et al. 2005). Fresh fruits are known to yield about 1.4 $3.7 \%$ red powder containing pigment Rottlerin (Siva 2007). A method of extraction of the dye from the fruit-pericarp of the tree has been already described and patented (Maeda et al. 2009). The red dye obtained from the tree is frequently used for preparing traditional Bhutanese fabrics and colouring silk clothes (Tshering 1996). This dye along with a mordant (Alum) is used for dyeing silk and wool clothes (Rao and Seshadri 1947; Siva 2007). This dye is believed to be superior for woollen and silk fabrics (Gaur 2009).

The Kamala powder is also used as a dyestuff in food (Gaur 2009; Rao and Seshadri 1947). The active compounds of the dye, rottlerin and its penta-potassium derivatives are employed for colouring foodstuffs, juices and other beverages (Caius 2012). Apart from colouring soaps, oils and ice creams (Rao and Seshadri 1947), it is also employed as an antioxidant for ghee (clarified butter) and vegetable oils (Rao and Seshadri 1947; Siva 2007). The powdered dye is widely used in perfume, leather and textile industry. The dyestuff finds applications in paintings and decorating wooden crafts especially by Bokshas (an indigenous community found in the Western region of Himalayas) (Gaur 2009). In Chromotherapy, the dye is used for body adornment (Gaur 2009). In addition to fruit powder, seed oil is used in painting and varnishing works (Caius 2012). The oil is also used as a substitute for Tung oil (Vernicia Lour., Euphorbiaceae) in the formulation of rapid drying paints, varnishes, hair fixers and ointments (Sierra et al. 2005).

The wood of the tree is a good source of fuel for household purposes (Dhanai et al. 2015; Samant et al. 2000; Sher et al. 2011; Zabihullah et al. 2006). In Australia, the wood is used for brush ware, flooring, and packing cases (Siva 2007). The wood is suitable for rafters, tool handles, matchboxes, and house-posts (Sierra et al. 2005). The leaves of the tree are good fodder sources and livestock fed on the leaves (Dhanai et al. 2015; Habib et al. 2016; Samant et al. 2000; Sierra et al. 2005). Thus, the tree has several important non-medicinal uses, which are very important from a socio-economic point of view.

\section{RESULTS}

Almost all the parts of the Kamala tree, are used for medicinal purposes either in single or combinatorial formulations by different tribal ethnic groups of the Indian subcontinent. For example, a mixture of roots, leaves and fruits of the tree with honey provides relief against biting of honeybee, scorpion and snakes (Adhikari et al. 2010; Subrahmanya 2012). On the other hand, fruit powder alone is effective against several worms (Akhtar and Ahmad 1992; Davis et al. 1995; Dikshit and Lalit 1970; Qasim et al. 2016; Usmanghani et al. 1997). Moreover, the tree has potential to cure health disorders ranging from most common ailments such as cough, cold and fever (Chassagne et al. 2016) to life-threatening diseases like cancer (Khan et al. 2013; 
Kulkarni et al. 2014; Tanaka et al. 2008). Various components of the plant (in powdered form) are known to cure common skin ailments (Reddy 1995). For example, a preparation made by mixing the powdered bark and leaf in butter is applied on sores and boils in Solan, Himachal Pradesh (Verma and Chauhan 2007) and for skin diseases in Azad Jammu and Kashmir in Pakistan (Rashid et al. 2015). Similarly, the local communities of Cuddappa district of Andhra Pradesh (Reddy 1996) and Bajaur Agency, Pakistan (Aziz et al. 2017), use plant powder for skin diseases and wound healing, respectively.

Various formulations prepared from this tree are most frequently used for helminthic infestations, dermatological and digestive disorders (Figure 3 ). These formulations not only vary among ethnic groups but also vary for the same ethnic group and same disorder (see Add File 1). Among the plant parts, fruit is the most common ingredient for formulations used to treat various health disorders followed by leaves and bark of the tree (Figure 4).

Fruits and leaves together constitute more than $60 \%$ of formulations used to treat various disorders. Further, the use of this tree for the treatment of helminthic infestations is most frequently cited $(63.7 \%)$, though, digestive disorders had a greater number of articles (27.46\%) as compared to helminthic infestations (22.54\%). The use of different plant parts also varied with the disease category. For example, helminthic infestations are frequently treated with fruits and whole plant whereas dermatological and

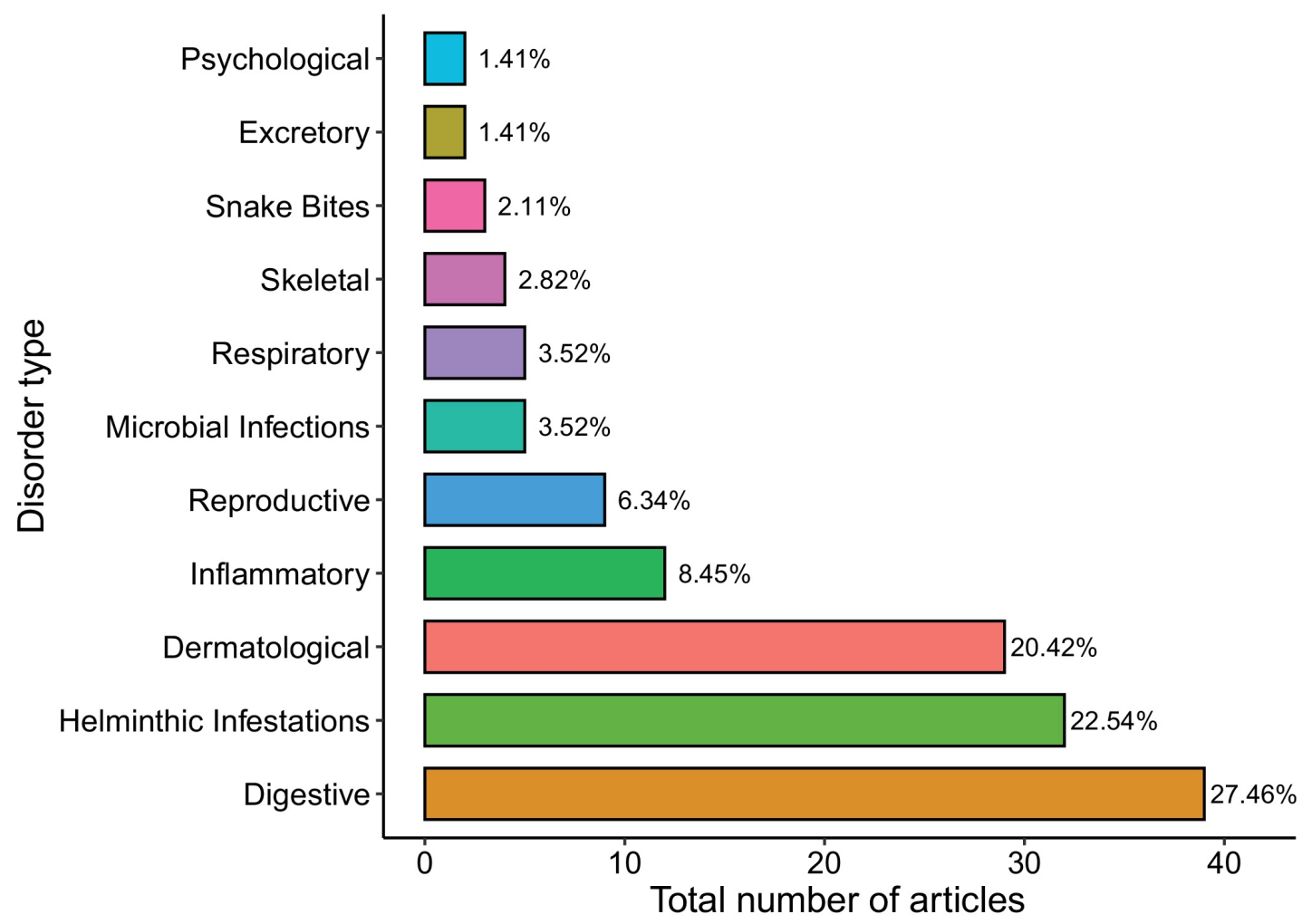

Figure 3. Bar diagram showing distribution of the articles $(n=142)$ according to cited their disorder categories. 


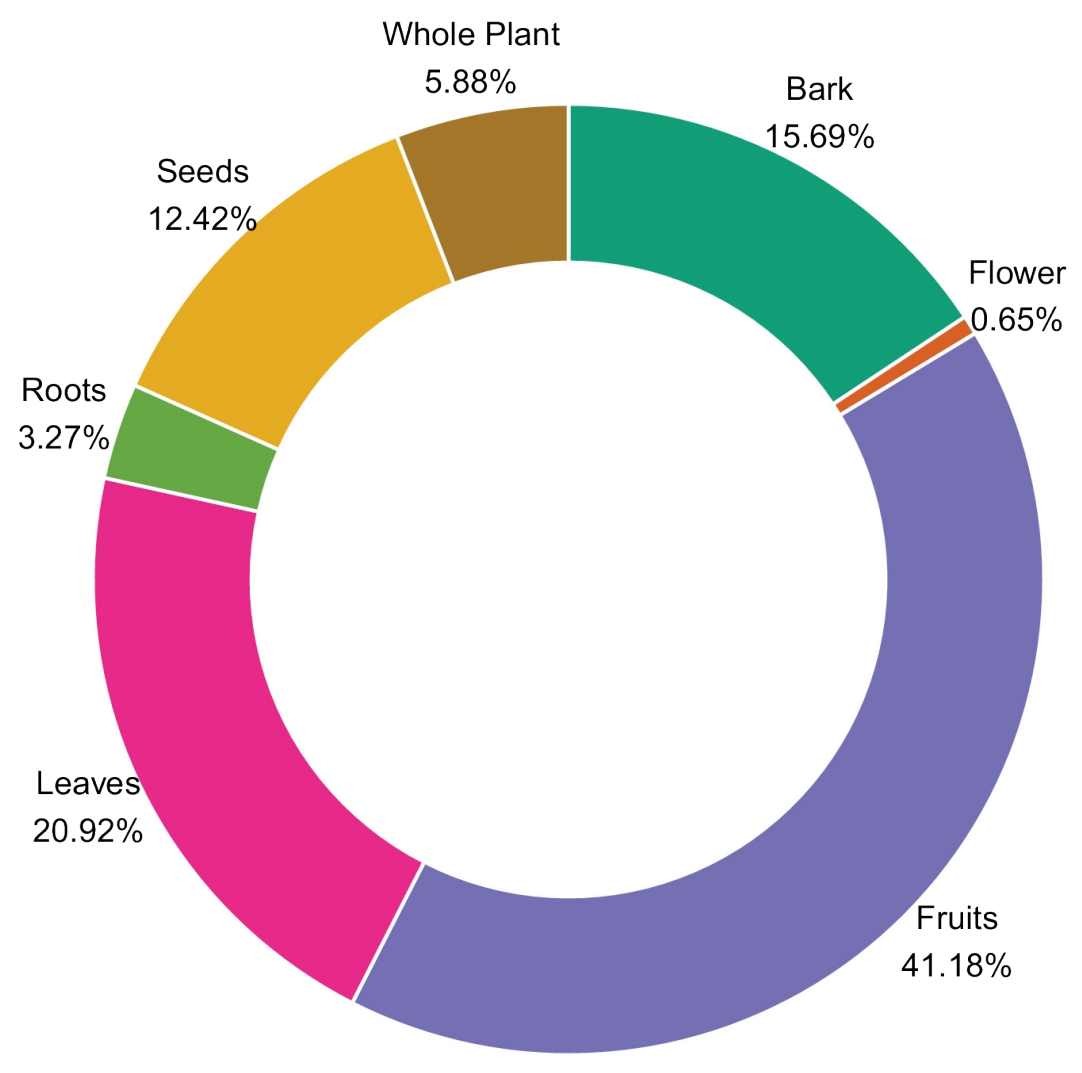

Figure 4. The frequency of plant parts used for the treatment of various disorders $(n=153)$.

digestive disorders are treated with bark, leaves and seeds (Figure 5). Furthermore, the Indian sub-continent is very diverse in culturally and linguistically delineated ethnic groups (Figure 6). However, the reported studies about the traditional uses among ethnic groups are relatively scarce, suggesting that the traditional uses of this particular are not be fully documented and there is a scope of further explorations. Next, we have discussed the major medicinal usage of different formulations prepared from this plant.

\section{Dermatological disorders}

Skin diseases like leprosy, itching, boils, scabies, ringworms, cuts and infections are often treated by directly applying formulations prepared from the various components of the tree. About $20 \%$ of total articles mentioned the use of this tree for skin-related disorders and $15 \%$ of total informants suggested its use for the same purpose. The fruit powder of this plant is often employed for various skin diseases such as scabies, herpes, ringworm, freckles, pityriasis and several bacterial caused skin problems (Khare 2007; Usmanghani et al. 1997).

The local people from Azad Jammu and Kashmir, Pakistan (Rashid et al. 2015) and the Solan district of Himachal Pradesh, India (Verma and Chauhan 2007) apply a paste (prepared by mixing powder of bark and leaves with butter) externally on skin affected with sores and boils. Similarly, the bark paste alone is used to stop bleeding from wounds by the Bhilla people of Maharashtra (Kamble et al. 2010) while the 


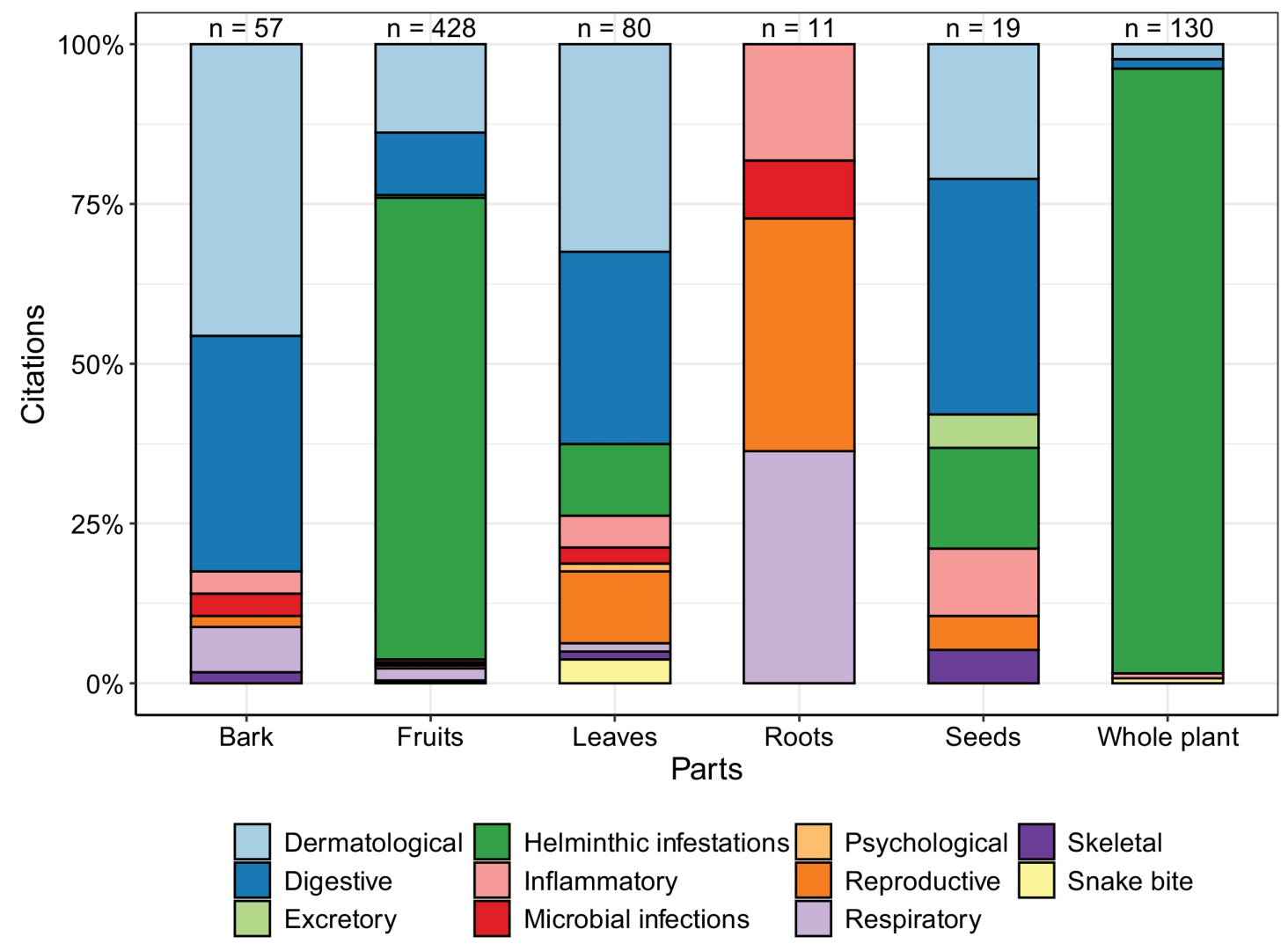

Figure 5. The stacked bar showing the usage of each plant part to different categories of the disorders. The total number of citations of particular plant parts are given at the top of each bar.

local people from Satpura hills use the bark paste to treat skin burns (Kosalge and Fursule 2009). Fruits are styptic and fruit hairs are used for scabies and cutaneous affections (Khare 2007; Siva 2007). The fruit powder mixing with a suitable oil is used for ringworms, skin irritation and wounds (Usmanghani et al. 1997). For example, the red powder from fruit pericarp mixed with mustard oil is applied externally twice a day for skin diseases and burns by the local people of Arghakhanchi district of Nepal (Panthi and Singh 2013) and Una district of Himachal Pradesh, India, respectively (Rana et al. 2017). On the other hand, the same powder is mixed with coconut oil and used for skin diseases and blisters of the ear in Rewa district of Madhya Pradesh, India (Shukla et al. 2010). Similarly, a paste prepared by mixing fruit powder with ghee (clarified butter) is externally applied on boils and blisters by the local people of Kalahandi district of Orissa (Nayak et al. 2004) and sub-Himalayan region of Uttarakhand (Sharma et al. 2013). Moreover, the red colour powder is also used as an ointment for ringworm, freckles and pityriasis (a type of skin rash) and also applied over syphilitic ulcers (Usmanghani et al. 1997). The local people of the North-West Frontier Province of Pakistan (Abbasi et al. 2010b) and the Tharu community of the Uttarakhand, India (Sharma et al. 2014) directly apply the juice prepared from the crushed leaves to cure skin diseases such as boils, ringworms, cuts and wounds. On the other hand, the people from adjacent Chirang Forest Reserve of Assam, India take a cold decoction of leaves for similar problems (Panda et al. 2018). In Bhopal, India, the external application of a 


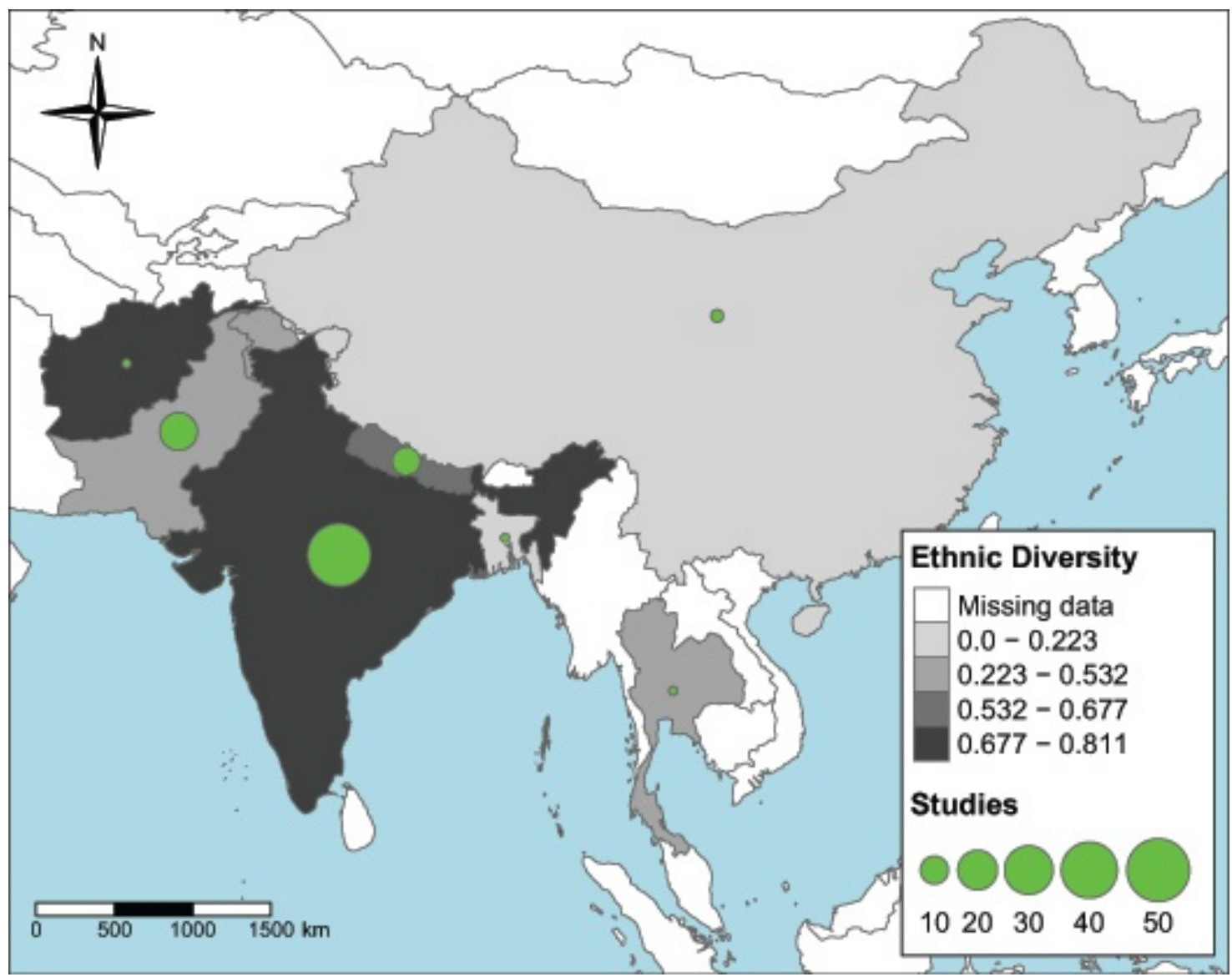

Figure 6. The total number of studies reporting the traditional uses of Mallotus philippensis is relatively scarce as compared to the ethnic diversity (based on Fearon 2003) of the countries in which plant is distributed.

mixture prepared from seed powder of Kamala mixed with sulphur, sawdust of Dalbergia sissoo DC. and sandalwood oil provides relief against dermatitis (Khan and Chaghtai 1982) while in Andhra Pradesh a paste prepared from the whole plant or any part in powdered form is applied externally for skin diseases (Reddy 1995, 1996). The fruit powder from pericarp is taken internally with other suitable drugs for relieving leprous affections in Pakistan (Usmanghani et al. 1997) and Madhya Pradesh state of India (Gupta et al. 2018). The wound injuries and skin infections of pigs and other domestic animals are cured by external application of seed powder in Sikkim Himalayas (Bharati and Sharma 2010, Bharati and Sharma 2012). A paste prepared from ground fruits and rhizome of Curcuma longa L. is known to stop bleeding when applied on wounds (Bhatia et al. 2014). In Una and Hamirpur districts of Himachal Pradesh, local people use fruit oil for skin diseases. In the same region, a poultice prepared from all the plant parts with rice-water (the thick liquid left after boiling rice) is used for ulcers, sores and swellings (Chand et al. 2016).

\section{Digestive disorders}

According to Ayurveda fruits are useful for abdominal diseases (Ahmad et al. 2009) and abdominal pain is still treated by taking a decoction of bark in the Bay island of Andaman and Nicobar Islands (Das et al. 2006) and Uttar Pradesh (Singh and Singh 2009) whereas a cold decoction of leaves is taken by the local people of the Chirang 
Reserve Forest in Northeast India (Panda et al. 2018). Moreover, Raute people of Nepal treat indigestion by taking 3 teaspoons of bark juice four times a day (Manandhar 1998). Constipation is often treated by taking fruits either as an extract or red powder of pericarp in Western Himalayan region, Orissa and Andhra Pradesh of India (Chand et al. 2016; Malik et al. 2015; Nayak et al. 2004; Reddy 1995). However, tribal inhabitants of Abbottabad district, Pakistan use dried seed powder mixed with curd for constipation (Abbasi et al. 2010a). Fruits are useful for the diabetic people and a decoction of fruits (prepared by boiling few fruits of Mallotus philippensis (Lam.) Müll. Arg. and seeds of Syzygium cuminii (L.) Skeels in about $200 \mathrm{ml}$ of cow's milk) is taken twice a day for a period of about one month to treat diabetes (Khare 2007; Maruthupandian et al. 2011; Seethapathy et al. 2018). On the other hand, the Taungya people of Uttar Pradesh take a teaspoon of seed powder (once a day) for lowering blood glucose levels and purgation (Poonam and Singh 2009).

An indigenous community, the Tharus is a culturally and linguistically diverse ethnic group, that lives along the Indo-Nepal border in the region known as Terai. These local people frequently take 3-4 teaspoon of bark juice thrice a day for diarrhoea and dysentery in Nawalparasi, Rupandehi and Palpa districts and the Western Terai region of Nepal (Acharya and Acharya 2010; Ghimire and Bastakoti 2009; Mahato and Chaudhary 2005; Taylor et al. 1996b). On the other hand, local people of Malakand Pass Hills, Pakistan (Barkatullah et al. 2015) and Kalahandi district of Orissa (Nayak et al. 2004) take fruit preparations orally to treat diarrhoea. Many local communities such as nomadic Gujjars, Tharu and Bhoxa treat Jaundice by taking small tablets prepared from seed powder with cold water in Uttarakhand and Himachal Pradesh states of India (Sharma et al. 2012a; Verma and Chauhan 2007).

Stomach disorders are treated by the application of various components and formulations. Stem bark and leaves are used by the local people of hilly areas in Tamil Nadu for stomach pain (Seethapathy et al. 2018) or bark juice can also be taken directly. A decoction of stem-bark and leaf of the tree (locally called as 'Kutthu Senkalai') with stem bark of Madhuca longifolia (J. Koenig ex L.) J. F. Macbr., the root bark of Phyllanthus emblica L. and fruits of Phoenix dactylifera $\mathrm{L}$. are used to cure stomach pain by Kani people in Tirunelveli hills of Tamil Nadu, India (Ayyanar and Ignacimuthu 2005). On the other hand, local people of Western Nepal either take seed decoction or a paste prepared from powder of this plant mixed with roots of Saccharum spontaneum L., fruit powder/paste of Piper longum L., root juice of Tinospora cordifolia (Willd.) Miers and root juice of Cheilanthes dalhousiae Hook. is used for stomach ache (Uprety et al. 2011). Red fruit powder mixed with water or bark juice is also taken for gastric disorders (Das et al. 2006; Ghimire and Bastakoti 2009). Fruits are generally considered as purgatives by the local people of Kot Manzaray Baba Valley (Zabihullah et al. 2006) Margala Hills National Park, Islamabad (Ahmad et al. 2009) and Chagharzai Valley of Pakistan (Sher et al. 2011). The Palliyar people of Sirumalai hills, in Tamil Nadu boil few fruits of Mallotus philippensis (Lam.) Müll. Arg. with seeds of Syzygium cuminii (L.) Skeels in $200 \mathrm{ml}$ of cow's milk. The decoction so obtained is taken twice a day for a period of about one month to treat diabetes (Maruthupandian et al. 2011). Leaves are considered carminative by local people of Mount Abu region of 
Rajasthan (Gupta 2015) and Azad Jammu and Kashmir region of Pakistan (Rashid et al. 2015) whereas local people of Kalahandi district in Orissa consider them as appetizers (Nayak et al. 2004).

\section{Excretory disorders}

The local people of Kalahandi district and Simlipal Biosphere reserve of Odisha, India take orally a paste prepared from fruits or fruits and seeds both to treat urinary infections (Nayak et al. 2004; Panda 2014).

\section{Helminthic infestations}

The anthelmintic potential of Kamala fruits finds frequent mention in ancient literature of India and Pakistan (Khare 2007; Nadkarni 1976; Usmanghani et al. 1997). Kamala, the powdered glandular hairs of fruits have anthelmintic properties (Ahmad et al. 2009; Ahmed and Siddiqa 2013; Malik et al. 2015; Nadkarni 1976; Qasim et al. 2016; Sher et al. 2011; Sierra et al. 2005; Siva 2007; Usmanghani et al. 1997) and it expels intestinal worms through purgation either dead or alive. Various formulations prepared from the fruits of this tree are used against several gastrointestinal worms such as tapeworms (Akhtar and Ahmad 1992; Chand et al. 2016), liver flukes, lungworms (Davis et al. 1995), threadworms, roundworms and hookworms (Das et al. 2006). This property makes fruit powder an essential constituent for Ayurvedic formulations like Krimighatni Bati and Krimikuthar Rasa that are important drugs used as anthelmintic. Both of these products are manufactured by Ayurveda based companies like Baidyanath (Kolkata, India) and Zandu (Mumbai, India).

The International veterinary community recognises the fruits of Mallotus philippensis (Lam.) Müll. Arg. as an effective treatment for tapeworms in goats, dogs, cats and other animals (Akhtar and Ahmad 1992). The Pashtun Kuchi nomads of Afghanistan employ fruit powder for the treatment of small ruminants infected with liver flukes, gastrointestinal worms, lungworms, internal parasites, and their toxins (Davis et al. 1995). Similarly, fruit powder is also given for curing Barber's pole worm (Haemonchus contortus (Rudolphi, 1803) Cobb, 1898) infestation in small ruminants of Punjab, Pakistan (Qasim et al. 2016) and for helminthic infestation of camels in Kathua district of Jammu \& Kashmir, India (Sharma and Manhas 2015). On the other hand, seeds are given to pigs in Sikkim Himalayas for intestinal worms (Bharati and Sharma 2012) while seed powder with curd or lassi (buttermilk) is given to animals in Hamirpur district of Himachal Pradesh (Bhatti et al. 2017) to kill intestinal worms.

Fruit powder mixed with curd is a frequent treatment for common ailments of animals such as an infestation of internal parasites (Bhatia et al. 2014; Sharma et al. 2012b). However, the dosage and formulations vary not only within the same regional areas but also in different localities of the Indian subcontinent. For example, more than 10 types of preparations and dosage administration are reported only from Sahiwal district of Punjab, Pakistan alone (Hussain et al. 2008). Doses are prepared by mixing 4 drams ( 1 dram $=1.77 \mathrm{~g}$ approx.) of fruit powder with $0.5 \mathrm{~L}$ of milk (or milk whey) or curd or mustard oil and administered per os. Fruit powder is also administered with milk (10 $\mathrm{g}$ fruit powder with $0.5 \mathrm{~L}$ of milk) or water (50 g fruit powder with $0.5 \mathrm{~L}$ of water) or with jaggery (10 $\mathrm{g}$ fruit powder mixed with jaggery). In another dosage preparation, $10 \mathrm{~g}$ of each powdered fruits of Mallotus philippensis (Lam.) Müll. Arg. and Tamarix aphylla (L.) H. Karst. and 
seeds of Brassica campestris L. mixed with $0.5 \mathrm{~L}$ of mustard oil and $0.5 \mathrm{~kg}$ of curd and administered per os. In Cholistan desert of Pakistan, about 100-200 g of fruits soaked in $500 \mathrm{~g}$ of yoghurt are given to livestock for the treatment of parasitic diseases (Farooq et al. 2008). Moreover, the herdsmen of Muzaffargarh district of Punjab, Pakistan give fruits with jaggery (Jabbar et al. 2006) while in Hassan district of Karnataka (India), it is given along with wheat flour (Kumar and Nagayya 2017) for curing intestinal worms in ruminants and other livestock animals.

The anthelminthic use of this tree for human beings is relatively less frequent as compared to animals. Several ethnic groups and local communities still traditionally utilise fruits as purgative and anthelmintic agents for human beings in India as well as Pakistan (Jabbar et al. 2006; Khare 2007; Sher et al. 2011). A fruit decoction in Purulia district of West Bengal (Chakraborty and Bhattacharjee 2006) and an extract prepared by boiling the fruits with common salt in Dehradun area of Uttarakhand is used as an anthelmintic (Jain and Puri 1984). The local inhabitants of Western Himalayan region (Malik et al. 2015; Rao et al. 2015; Rashid et al. 2015) and Bay Island of Andaman and Nicobar Islands (Das et al. 2006) eat fruits orally for killing the gastro-intestinal worms such as threadworms, hookworms and roundworms. As far as dosage is considered, in India, a single dose of $1 \mathrm{~g}$ Kamala powder for children $\leq 5$ years and 2 $\mathrm{g}$ for children $\geq 5$ years has been reported to eradicate $96 \%$ of the dwarf tapeworm (Hymenolepis nana (Bilharz, 1851) Ransom, 1901) infection (Dikshit and Lalit 1970). Although most of the studies employ fruits as the most common treatment of helminthic infestations, there are few reports where other parts of the tree were also used. For example, tribal inhabitants of Abbottabad district in Pakistan uses dried seed powder mixed with curd for killing intestinal worms and constipation (Abbasi et al. 2010a). Similarly, the whole plant is used for tapeworms by the Tharus of Nepal (Ghimire and Bastakoti 2009) and the local people of Rawalpindi district of Pakistan (Saqib et al. 2014). The Malamalasar people of Kerala use a decoction of flowers for tapeworms (Yesodharan and Sujana 2007). Thus, the above discussion shows that the fruits are almost exclusively used for the anthelmintic purpose and about 380 informants from 15 studies have reported the use of the tree as anthelmintic.

\section{Inflammatory disorders}

Some fevers developed due to inflammation such as the puerperal fever are treated by taking either whole plant powder (Ghimire and Bastakoti 2009) or tablets prepared from a paste of leaves of Mallotus philippensis (Lam.) Müll. Arg., tubers of Colocasia esculenta (L.) Schott., the bark of Cinnamomum verum J. Presl, camphor, the fruit of Piper cubeba L.f., leaf of Scoparia dulcis L., the fruit of Ficus scandens Lam., the clove of Syzygium aromaticum (L.) Merr. \& L. M. Perry, the fruit of Amomum subulatum Roxb., the fruit of Amomum aromaticum Roxb., the fruit of Piper longum L., the rhizome of Curcuma zedoaria Roxb., top of the stem with the leaf of Bambusa tulda Roxb., leaf pulp of Aloe vera (L.) Burm.f., the rhizome of Alpinia nigra (Gaertn.) Burtt, and calcined copper, lead, iron, brass, any colour and bell metal (Ahmed et al. 2017). However, local people from Limu mountains of Hainan Island (China) treat headache by external application of toasted leaves of the tree (Zheng et al. 2013). Almost all the parts of the tree can be used for the treatment of 
rheumatism. For example, to get relief from rheumatism bark decoction is taken internally in Kerala and Karnataka region of India (Subrahmanya 2012) while leaf decoction is used in Solan district of Himachal Pradesh, India (Verma and Chauhan 2007). In Western Ghats of Tamil Nadu, a paste is prepared by mixing an equal amount of leaves and tender fruits in honey. This paste is taken twice a day for 13 days to get relief from rheumatism (Sutha et al. 2010). Among the Mundas of Chota Nagpur (India), well-ground roots are rubbed on the rheumatic joints (Kirtikar and Basu 1935) while in Orrisa (= Odisha) local people also use root-bark for arthritis and rheumatism (Biswas 2012). In Bhopal, India, the external application of a mixture prepared from seed powder of Kamala mixed with sulphur, sawdust of Dalbergia sissoo DC. and sandalwood oil provides relief in rheumatic joints and dermatitis when applied externally (Khan and Chaghtai 1982) whereas only seed paste is externally applied for rheumatism in Andhra Pradesh (Reddy 1995). In addition to these, bark juice is taken for meningitis in Nepal (Ghimire and Bastakoti 2009) and fruit decoction is used for enlarged spleen in children of West Bengal (Chakraborty and Bhattacharjee 2006).

\section{Microbial infections}

Limited information is available about the traditional use of this plant for microbial infections. Bark has antibacterial and antiviral properties (Taylor et al. 1996a) and used against microbial infections. In Southern parts of India, oil prepared from leaves is applied on the head for cold and running noses (Subrahmanya 2012). Local inhabitants of Solan, Himachal Pradesh believes that roots of this tree can treat poliomyelitis and they traditionally use to tie small roots around the neck of polio-affected children (Verma and Chauhan 2007).

\section{Psychological disorders}

Fruits have cathartic properties (Khare 2007; Usmanghani et al. 1997). Similarly, leaf paste prepared with eggs of the hen is applied on eyes for treating dizziness among the ethnic groups (Korku tribe) in Amravati district of Maharashtra, India (Jagtap et al. 2006).

\section{Reproductive disorders}

The decoction of stem-bark and leaf of the tree (locally called as 'Kutthu Senkalai') with stem bark of Madhuca longifolia (J. Koenig ex L.) J. F. Macbr., the root bark of Phyllanthus emblica L. and fruits of Phoenix dactylifera $\mathrm{L}$. are used to cure hydrocele and stomach pain by Kani people in Tirunelveli hills of Tamil Nadu, India (Ayyanar and Ignacimuthu 2005). The Reang people of Tripura state of India treat leucorrhoea by eating curry of leaf buds (Shil et al. 2014) while the local Tai Yai people of Thailand eat the boiled roots for treating leucorrhoea (Khuankaew et al. 2014). Menstrual disorders are treated by taking internally fruit paste or a paste of fruits and seeds both by the local inhabitants in Odisha (Nayak et al. 2004; Panda 2014). The juice is prepared by crushing leaves of Mallotus philippensis (Lam.) Müll. Arg., leaves of Rungia pectinata (L.) Nees. and fruits of Piper longum L. About half cup of this juice is taken for 4-5 days to regularize un-periodic menstruation by local people of Nasik district of Maharashtra (Patil and Patil 2004). 


\section{Respiratory disorders}

The local Tai Yai people of Thailand take orally the boiled roots for treating allergic asthma (Khuankaew et al. 2014). The local people of Nepal treat bronchitis by drinking bark juice of the tree (Acharya and Acharya 2010; Ghimire and Bastakoti 2009). Local tribal-healers of Madhya Pradesh employ fruits for tuberculosis, chest complaints, leprosy and wounds (Gupta et al. 2018). Local communities of Shahjahanpur, Uttar Pradesh take leaf powder for cough (Sharma et al. 2010).

\section{Skeletal disorders}

A mixture of bark paste, white of egg, two prawns, prop roots of Pandanus odoratissimus L.f. is kept overnight and applied externally on fractured bones by Kurichiar people of Kerala (Udayan et al. 2008). Fruits are considered spasmolytic (Khare 2007) while leaves are used for relieving muscular pain by people of Tamil Nadu (Ganesan et al. 2009).

\section{Snake Bites}

Leaves are also implicated against stings and bites of poisonous animals (Sierra et al. 2005). The Nicobarese people of Car Nicobar Island, India use leaves to cure snake bites (Chander et al. 2014) whereas the people of Kerala and Karnataka apply powder prepared from the whole plant (Subrahmanya 2012).

\section{CONCLUSIONS}

The traditional knowledge regarding the medicinal uses of Kamala tree is being documented from the Indian subcontinent, but information from other South Asian countries is poorly represented in the literature. About $70 \%$ of the total articles mentioned the utility of the tree for helminthic infestations, dermatological and digestive disorders suggesting that the tree may have some active chemicals that are effective for treating these health ailments. Also, more than $90 \%$ of informants cited the use of this tree for various ailments belonging to these three categories. While, other disorders such as excretory, psychological and skeletal disorders are less reported indicating that either these usages are not extensively explored or the trees are less effective against these disorders. Furthermore, almost all the components of the tree are utilised for one or more therapeutic applications, but fruits known as Kamala are exclusively used for the helminthic infestations and skin problems.

Interestingly, few studies reported that some local communities use to treat some diseases such as cancer, tuberculosis, kidney-stones using preparations from this plant but it is questionable that how the local people identify such diseases that cannot be diagnosed externally. Further, some of the studies reporting medicinal uses lack of exact dosage and preparations, which have no meaning to science. Therefore, future ethnobotanical research needs to report dosage, formulations and their use as exact as possible, rather than reporting inadequate information. Also, the available information about traditional uses is relatively less represented in literature as compared to diversity and area covered by different ethnic groups. Hence, this suggests that many ethnic communities and geographical areas are not documented yet and there is a scope of further exploration and documentation of such information. 


\section{ACKNOWLEDGEMENTS}

Authors are grateful to the Chairperson, Department of Botany, Panjab University, Chandigarh, for providing all necessary facilities required for work. We are deeply grateful to Prof. Michael Heinrich, for his critical, valuable and constructive comments, which significantly improved this manuscript. We are also thankful to anonymous reviewers for their constructive and insightful suggestions.

\section{DATA AVAILABILITY}

All the data used to support the findings of this study are available in the Additional File 1.

\section{CONFLICTS OF INTEREST}

The authors have no conflicts of interest to declare.

\section{CONTRIBUTION STATEMENT}

Conceived the presented idea: ANS, RCB, NKS, RK. PK.

Carried out the literature survey: AK, MP,

Carried out the data analysis: AK, MP.

Wrote the first draft of the manuscript: NKS, RK, RCB.

Review: PK, RCB, RK, NKS, ANS.

Wrote the final manuscript: AK, MP, PK.

Carried out revisions: AK, ANS.

Supervision: ANS.

\section{REFERENCES}

Abbasi AM, Ajab Khan M, Ahmed M, Zafar M (2010a) Herbal medicines used to cure various ailments by the inhabitants of Abbottabad district, North West Frontier Province, Pakistan. Indian Journal of Traditional Knowledge 9:175-183
Abbasi AM, Khan MA, Ahmad M, Zafar M, Jahan S, Sultana S (2010b) Ethnopharmacological application of medicinal plants to cure skin diseases and in folk cosmetics among the tribal communities of North-West Frontier Province, Pakistan. Journal of Ethnopharmacology 128:322-335

Abbasi AM, Khan SM, Ahmad M, Khan MA, Quave CL, Pieroni A (2013) Botanical ethnoveterinary therapies in three districts of the Lesser Himalayas of Pakistan. Journal of Ethnobiology and Ethnomedicine 9:84

Acharya R, Acharya KP (2010) Ethnobotanical Study of Medicinal Plants used by Tharu Community of Parroha VDC, Rupandehi District, Nepal. Scientific World 7:80-84

Adhikari BS, Babu MM, Saklani PL, Rawat GS (2010) Medicinal Plants Diversity and their Conservation Status in Wildlife Institute of India (WII) Campus, Dehradun. Ethnobotanical Leaflets 14:46-83

Ahmad SS, Mahmood F, Dogar Z, lqbal Khan Z, Ahmad K, Sher M, Mustafa I, Elahi Valeem E (2009) Prioritization of medicinal plants of Margala Hills National Park, Islamabad on the basis of available information. Pakistan Journal of Botany 41:2105-2114

Ahmed E, Arshad M, Saboor A, Qureshi R, Mustafa G, Sadiq S, Chaudhari SK (2013) Ethnobotanical appraisal and medicinal use of plants in Patriata, New Murree, evidence from Pakistan. Journal of Ethnobiology and Ethnomedicine 9:13

Ahmed KMI, Bashar S, Tanny UT, Mandal BK, Islam E (2017) Ethnomedicinal formulations of a Garo tribal healer in Haluaghat, Mymensingh district, Bangladesh. Journal of Medicinal Plants Studies 5:219-223

Ahmed S, Siddiqa F (2013) Anthelmintic Activity of Unani Mallotus phillippienesis (Kamela). American Journal of Phytomedicine and Clinical Therapeutics 9:706-712

Akhtar MS, Ahmad I (1992) Comparative efficacy of Mallotus philippinensis fruit (Kamala) or Nilzan $®$ drug against gastrointestinal cestodes in Beetal goats. Small Ruminant Research 8:121-128

Ayyanar M, Ignacimuthu S (2005) Traditional knowledge of Kani tribals in Kouthalai of Tirunelveli hills, Tamil Nadu, India. Journal of Ethnopharmacology 102:246-255 
Aziz MA, Khan AH, Adnan M, Izatullah I (2017) Traditional uses of medicinal plants reported by the indigenous communities and local herbal practitioners of Bajaur Agency, Federally Administrated Tribal Areas, Pakistan. Journal of Ethnopharmacology 198:268-281

Bandopadhyay M, Dhingra VK, Mukerjee SK, Pardeshi NP, Seshadri TR (1972) Triterpenoid and other components of Mallotus Philippinensis. Phytochemistry 11:1511

Barkatullah, Ibrar M, Rauf A, Ben Hadda T, Mubarak MS, Patel S (2015) Quantitative ethnobotanical survey of medicinal flora thriving in Malakand Pass Hills, Khyber Pakhtunkhwa, Pakistan. Journal of Ethnopharmacology 169:335-346

Bharati KA, Sharma BL (2010) Some ethnoveterinary plant records for Sikkim Himalaya. Indian Journal of Traditional Knowledge 9:344-346

Bharati KA, Sharma BL (2012) Plants used as ethnoveterinary medicines in Sikkim Himalayas. Ethnobotany Research and Applications 10:339-356

Bhatia H, Sharma YP, Manhas RK, Kumar K (2014) Ethnomedicinal plants used by the villagers of district Udhampur, J\&K, India. Journal of Ethnopharmacology 151:1005-1018

Bhatti RC, Nirmala C, Kaur AD, Singh S, Mor PK, Kaur R, Singh AN, Nirmala C, Singh AN (2017) Harnessing of local plant species by indigenous people of Hamirpur district for ethno-veterinary purposes. Annals of Plant Sciences 6:1898-1925

Biswas S (2012) Ethnobotanical studies of Malkangiri district Orissa including identification of a few potential species for modern drug development programme. $\mathrm{PhD}$ Thesis, Utkal University, Bhubaneswar, Odisha, India

Caius JF (2012) The medicinal and poisonous plants of India. Scientific Publishers, Jodhpur, India

Chakraborty MK, Bhattacharjee A (2006) Some common ethnomedicinal uses for various diseases in Purulia district, West Bengal. Indian Journal of Traditional Knowledge 5:554558
Chand R, Kaur R, Kaur A, Kumar V, Nirmala C, Singh AN (2016) Assessment of Ethnomedicinal Plant Diversity of Una and Hamirpur District of Himachal Pradesh, India: An Ethno-ecological approach. Annals of Plant Sciences 5:1475-1490

Chander MP, Kartick C, Gangadhar J, Vijayachari P (2014) Ethno medicine and healthcare practices among Nicobarese of Car Nicobar - An indigenous tribe of Andaman and Nicobar Islands. Journal of Ethnopharmacology 158:18-24

Chassagne F, Hul S, Deharo E, Bourdy G (2016) Natural remedies used by Bunong people in Mondulkiri province (Northeast Cambodia) with special reference to the treatment of 11 most common ailments. Journal of Ethnopharmacology 191:41-70

Dahare D, Jain A (2010) Ethnobotanical Studies on Plant Resources of Tahsil Multai, District Betul, Madhya Pradesh, India. Ethnobotanical Leaflets 14:694-705

Daikonya A, Katsuki S, Kitanaka S (2004) Antiallergic agents from natural sources 9. Inhibition of nitric oxide production by novel chalcone derivatives from Mallotus philippinensis (Euphorbiaceae). Chemical \& Pharmaceutical Bulletin 52:1326-1329

Das S, Sheeja TE, Mandal AB (2006) Ethnomedicinal uses of certain plants from Bay Islands. Indian Journal of Traditional Knowledge 5:207-211

Davis DK, Quraishi K, Sherman D, Sollod A, Stem C (1995) Ethnoveterinary medicine in Afghanistan: an overview of indigenous animal health care among Pashtun Koochi nomads. Journal of Arid Environments 31:483500

Dhaker JK, Sharma K (2014) Ethnopharmacology review on Endangered Medicinal plant. International Journal of Pharmacy \& Biomedical Research 1:1-6

Dhanai R, Negi RS, Singh S, Parmar MK (2015) Fuelwood Consumption by Villagers in Different Altitudinal Gradient: A Case of Takoligad Watershed of Garhwal Himalaya, India. International Journal of Current Engineering and Technology 5:72-80

Dikshit SK, Lalit OP (1970) Hymenolepiasis in childhood and its treatment by indigenous drugs. Indian Journal of Medical Research 58:616-21 
Farooq Z, Iqbal Z, Mushtaq S, Muhammad G, lqbal MZ, Arshad M (2008) Ethnoveterinary practices for the treatment of parasitic diseases in livestock in Cholistan desert (Pakistan). Journal of Ethnopharmacology 118:213-219

Fearon JD (2003) Ethnic and Cultural Diversity by Country*. Journal of Economic Growth 8: 195-222

Ganesan S, Ponnuchamy M, Kesavan L, Selvaraj A (2009) Floristic composition and practices on the selected sacred groves of Pallapatty village (Reserved forest), Tamil Nadu. Indian Journal of Traditional Knowledge 8:154-162

Gangwar M, Gautam MK, Sharma AK, Tripathi YB, Goel RK, Nath G (2014a) Antioxidant capacity and radical scavenging effect of polyphenol rich Mallotus philippenensis fruit extract on human erythrocytes: An in vitro study. Scientific World Journal 2014:279451

Gangwar M, Goel RK, Nath G (2014b) Mallotus philippinensis Muell. Arg (Euphorbiaceae): Ethnopharmacology and phytochemistry review. BioMed Research International 2014:213973

Gangwar M, Kumar D, Tilak R, Singh TD, Singh SK, Goel R, Nath G (2011) Qualitative Phytochemical Characterization and Antibacterial Evaluation of Glandular Hairs of Mallotus philippinensis Fruit Extract. Journal of Pharmacy Research 4:4214-4216

Gaur RD (2009) Traditional dye yielding plants of Uttarakhand, India. Natural Product Radiance 7:154-165

Ghimire K, Bastakoti RR (2009) Ethnomedicinal knowledge and healthcare practices among the Tharus of Nawalparasi district in central Nepal. Forest Ecology and Management 257:2066-2072

Goraya K, Iqbal Z, Sajid MS, Muhammad G, Ain Q ul, Saleem M (2013) Diversity of flora used for the cure of equine diseases in selected peri-urban areas of Punjab, Pakistan. Journal of Ethnobiology and Ethnomedicine 9:70

Gupta AG (2015) Ethnobotanical studies of mount Abu region in Sirohi district Rajasthan. PhD Thesis, University of Rajasthan, Jaipur, Rajasthan, India
Gupta VK, Kaushik A, Chauhan DS, Ahirwar RK, Sharma S, Bisht D (2018) Anti-mycobacterial activity of some medicinal plants used traditionally by tribes from Madhya Pradesh, India for treating tuberculosis related symptoms. Journal of Ethnopharmacology 227:113-120

Habib G, Khan NA, Sultan A, Ali M (2016) Nutritive value of common tree leaves for livestock in the semi-arid and arid rangelands of Northern Pakistan. Livestock Science 184:6470

Hamayun M, Khan A, Khan MA (2005) Common Medicinal Folk Recipes of District Buner, NWFP, Pakistan. Ethnobotanical Leaflets 2005:45

Haque Z, Ahmed T, Mand D, Asma K, Rumman, Alam A (2015) Medicinal Effect of Kameela and Amraze Jildiya (Skin Diseases) Described in Unani System of Medicine and Current Research-An Overview. International Journal of Pharmacognosy 2:494-496

Hussain A, Khan MN, Iqbal Z, Sajid MS (2008) An account of the botanical anthelmintics used in traditional veterinary practices in Sahiwal district of Punjab, Pakistan. Journal of Ethnopharmacology 119:185-190

Jabbar A, Raza MA, Iqbal Z, Khan MN (2006) An inventory of the ethnobotanicals used as anthelmintics in the southern Punjab (Pakistan). Journal of Ethnopharmacology 108:152-154

Jagtap SD, Deokule SS, Bhosle S V. (2006) Some unique ethnomedicinal uses of plants used by the Korku tribe of Amravati district of Maharashtra, India. Journal of Ethnopharmacology 107:463-469

Jain SP, Puri HS (1984) Ethnomedicinal plants of Jaunsar-Bawar hills, Uttar Pradesh, India. Journal of Ethnopharmacology 12:213-22

Joshi AR, Joshi K (2007) Ethnomedicinal Plants Used Against Skin Diseases in Some Villages of Kali Gandaki, Bagmati and Tadi Likhu Watersheds of Nepal. Ethnobotanical Leaflets 11:235-246

Kala CP, Dhyani PP, Sajwan BS (2006) Developing the medicinal plants sector in northern India: Challenges and opportunities. Journal of Ethnobiology and Ethnomedicine 2:32 
Kamble SY, Patil SR, Sawant PS, Sawant S, Pawar SG, Singh EA (2010) Studies on plants used in traditional medicine by Bhilla tribe of Maharashtra. Indian Journal of Traditional Knowledge 9:591-598

Khan M, Qureshi RA, Hussain M, Mehmood K, Khan RA (2013) Hexane soluble extract of Mallotus philippensis (Lam.) Muell. Arg. root possesses anti-leukaemic activity. Chemistry Central Journal 7:157

Khan S, Chaghtai S (1982) Ethnobotanical study of some plants used for curing skin afflictions. Ancient Science of Life 1:236-238

Khare CP (2007) Indian Medicinal Plants- An Illustrated Dictionary. Springer, New York

Khuankaew S, Srithi K, Tiansawat $P$, Jampeetong A, Inta A, Wangpakapattanawong $P$ (2014) Ethnobotanical study of medicinal plants used by Tai Yai in Northern Thailand. Journal of Ethnopharmacology 151:829-838

Kirtikar KR, Basu BD (1935) Indian Medicinal Plants. 2 ed. Lalit Mohan Basu, Allahabad, India

Kosalge SB, Fursule RA (2009) Investigation of ethnomedicinal claims of some plants used by tribals of Satpuda Hills in India. Journal of Ethnopharmacology 121:456-461

Kulkarni RR, Tupe SG, Gample SP, Chandgude MG, Sarkar D, Deshpande M V., Joshi SP (2014) Antifungal dimeric chalcone derivative Kamalachalcone E from Mallotus philippinensis. Natural Product Research 28:245-250

Kumar GMP, Nagayya S (2017) Utilization of ethno-veterinary medicinal plants in Hassan district of Karnataka, India. International Journal of Pharmacy and Pharmaceutical Sciences 9:107

Kumar R, Bharati KA (2014) Ethnomedicines of Tharu tribes of Dudhwa National Park, India. Ethnobotany Research and Applications 12:001013

Lamarck J-B, Poiret J-L-M (1786) Encyclopédie méthodique. Botanique. Panckoucke, Paris

Lounasmaa M, Widen CJ, Tuuf CM, Huhtikangas A (1975) On the phloroglucinol derivatives of Mallotus philippinensis. Planta Medica 28:1631

Maeda M, Fukami H, Namikawa K (2009) Method for producing Mallotus philippinensis dye composition and the composition.
Mahato RB, Chaudhary RP (2005) Ethnomedicinal study and antibacterial activities of selected plants of Palpa district, Nepal. Scientific World 3:26-31

Malik ZA, Bhat JA, Ballabha R, Bussmann RW, Bhatt AB (2015) Ethnomedicinal plants traditionally used in health care practices by inhabitants of Western Himalaya. Journal of Ethnopharmacology 172:133-144

Manandhar NP (1998) Native phytotherapy among the Raute tribes of Dadeldhura district, Nepal. Journal of Ethnopharmacology 60:199-206

Maruthupandian A, Mohan VR, Kottaimuthu R (2011) Ethnomedicinal plants used for the treatment of diabetes and jaundice by Palliyar tribals in Sirumalai hills, Western Ghats, Tamil Nadu, India. Indian Journal of Natural Products and Resources 2:493-497

Müller J (1865) Euphorbiaceae. Linnaea 34:1224

Nadkarni AK (1976) Dr. K. M. Nadkarni's Indian Materia Medica: with ayurvedic, unani-tibbi, siddha, allopathic, homeopathic, naturopathic $\&$ home remedies, appendices \& indexes. Popular Book Depot, Bombay and Dhootapapeshwar Prakashan Ltd, Panvel, India

Nayak S, Behera SK, Misra MK (2004) Ethnomedico-botanical survey of Kalahandi district of Orissa. Indian Journal of Traditional Knowledge 3:72-79

Panda SK (2014) Ethno-medicinal uses and screening of plants for antibacterial activity from Similipal Biosphere Reserve, Odisha, India. Journal of Ethnopharmacology 151:158175

Panda SK, Das R, Leyssen P, Neyts J, Luyten W (2018) Assessing medicinal plants traditionally used in the Chirang Reserve Forest, Northeast India for antimicrobial activity. Journal of Ethnopharmacology 225:220233

Panthi MP, Singh AG (2013) Ethnobotany of Arghakhanchi District, Nepal: Plants used in dermatological and cosmetic disorders. International Journal of Applied Sciences and Biotechnology 1:27-32

Patil M V, Patil DA (2004) Plants used in reproductive ailments by tribals of Nasik district (Maharashtra). Ancient Science of Life 23:37-41 
Pattanaik C, Reddy CS, Dhal NK, Das R (2006) Some Phytotherapeutic Claims by Tribals of Rayagada District, Orissa, India. Ethnobotanical Leaflets 10:189-197

Poonam K, Singh GS (2009) Ethnobotanical study of medicinal plants used by the Taungya community in Terai Arc Landscape, India. Journal of Ethnopharmacology 123:167176

Qasim HM, Avais M, Durrani AZ, Khan MA, Shahzad AH (2016) Dynamic dispersal of haemonchosis, its treatment and effect on blood profile of small ruminants of Lodhran district, Punjab, Pakistan. Pakistan Journal of Zoology 48:755-761

R Core Team (2018) R: A language and environment for statistical computing. $R$ Foundation for Statistical Computing, Vienna, Austria. Available from: http://www.R-project.org/

Rana M, Rana M, Sharma D, Chauhan P (2017) Commonly used Medicinal Plants in Tehsil Bangana, District Una, Himachal Pradesh. Journal of Ayurvedic and Herbal Medicine 3:102107

Rao PK, Hasan SS, Bhellum BL, Manhas RK (2015) Ethnomedicinal plants of Kathua district, J\&K, India. Journal of Ethnopharmacology 171:12-27

Rao VS, Seshadri TR (1947) Kamala dye as an anthelmintic. Proceedings of the Indian Academy of Sciences, Section A 26:178-181

Rashid S, Ahmad M, Zafar M, Sultana S, Ayub M, Khan MA, Yaseen G (2015) Ethnobotanical survey of medicinally important shrubs and trees of Himalayan region of Azad Jammu and Kashmir, Pakistan. Journal of Ethnopharmacology 166:340-351

Reddy RV (1995) Ethnobotanical and phytochemical studies on medicinal plant resources of Cuddapah district A P India. PhD Thesis, Sri Krishnadevaraya University, Anantapur, Andhra Pradesh, India

Reddy SR (1996) Floristic and ethnobotanical studies on Lankamala hills Cuddapah district A P. PhD Thesis, Sri Krishnadevaraya University, Anantapur, Andhra Pradesh, India

Rivière $C$, Nguyen Thi Hong $V$, Tran Hong $Q$, Chataigné $\mathrm{G}$, Nguyen Hoai $\mathrm{N}$, Dejaegher $\mathrm{B}$, Tistaert C, Nguyen Thi Kim T, Vander Heyden Y, Chau Van M, Quetin-Leclercq J (2010) Mallotus species from Vietnamese mountainous areas: Phytochemistry and pharmacological activities. Phytochemistry Reviews 9:217-253
Roberts KD, Weiss E, Reichstein T (1963) Die Cardenolide der Samen von Mallotus philippinensis (LAM.) MÜLL. -ARG. (= Rottlera tinctoria ROXB.). Glykoside und Aglykone, 252. Mitteilung. Helvetica Chimica Acta 46:28862893

Saijo R, Nonaka G, Nishioka I (1989) Tannins and related compounds. LXXXIV. Isolation and characterization of five new hydrolyzable tannins from the bark of Mallotus japonicus. Chemical \& Pharmaceutical Bulletin 37:2063-70

Samant SS, Dhar U, Rawal RS (2000) Assessment of fuel resource diversity and utilization patterns in Askot Wildlife Sanctuary in Kumaun Himalaya, India, for conservation and management. Environmental Conservation 27:5-13

Saqib Z, Mahmood A, Naseem Malik R, Mahmood A, Hussian Syed J, Ahmad T (2014) Indigenous knowledge of medicinal plants in Kotli Sattian, Rawalpindi district, Pakistan. Journal of Ethnopharmacology 151:820-828

Seethapathy GS, Ravikumar K, Paulsen BS, de Boer HJ, Wangensteen H (2018) Ethnobotany of dioecious species: Traditional knowledge on dioecious plants in India. Journal of Ethnopharmacology 221:56-64

Shanmugam S, Gayathri N, Sakthivel B, Ramar S, Rajendran K (2009) Plants used as Medicine by Paliyar Tribes of Shenbagathope in Virudhunagar District of Tamilnadu, India. Ethnobotanical Leaflets 13:370-378

Sharma J, Gairola S, Gaur RD, Painuli RM (2012a) The treatment of jaundice with medicinal plants in indigenous communities of the Sub-Himalayan region of Uttarakhand, India. Journal of Ethnopharmacology 143:262291

Sharma J, Gairola S, Sharma YP, Gaur RD (2014) Ethnomedicinal plants used to treat skin diseases by Tharu community of district Udham Singh Nagar, Uttarakhand, India. Journal of Ethnopharmacology 158:140-206

Sharma J, Gaur RD, Gairola S, Painuli RM, Siddiqi TO (2013) Traditional herbal medicines used for the treatment of skin disorders by the Gujjar tribe of Sub-Himalayan tract, Uttarakhand. Indian Journal of Traditional Knowledge 12:736-746

Sharma J, Painuli RM, Gaur RD (2010) Plants used by the rural communities of district Shahjahanpur, Uttar Pradesh. Indian Journal of Traditional Knowledge 9:798-803 
Sharma J, Varma $R$ (2011) A review on endangered plant of Mallotus philippensis (Lam.) M. Arg. Pharmacologyonline 3:12561265

Sharma R, Manhas RK (2015) Ethnoveterinary plants for the treatment of camels in Shiwalik regions of Kathua district of Jammu \& Kashmir, India. Journal of Ethnopharmacology 169:170-175

Sharma R, Manhas RK, Magotra R (2012b) Ethnoveterinary remedies of diseases among milk yielding animals in Kathua, Jammu and Kashmir, India. Journal of Ethnopharmacology 141:265-272

Sher Z, Khan Z, Hussain F (2011) Ethnobotanical studies of some plants of Chagharzai valley, district Buner, Pakistan. Pakistan Journal of Botany 43:1445-1452

Shil S, Choudhury MD (2009) Indigenous Knowledge on Healthcare Practices by the Reang Tribe of Dhalai District of Tripura, North East India. Ethnobotanical Leaflets 13:775-790

Shil S, Dutta Choudhury M, Das S (2014) Indigenous knowledge of medicinal plants used by the Reang tribe of Tripura state of India. Journal of Ethnopharmacology 152:135141

Shukla AN, Srivastava S, Rawat AKS (2010) An ethnobotanical study of medicinal plants of Rewa district, Madhya Pradesh. Indian Journal of Traditional Knowledge 9:191-202

Sierra SEC, Van Welzen PC, Slik JWF (2005) A taxonomic revision of Mallotus section philippinenses (former section Rottlera Euphorbiaceae) in Malesia and Thailand. Blumea: Journal of Plant Taxonomy and Plant Geography 50:221-248

Singh A, Singh PK (2009) An ethnobotanical study of medicinal plants in Chandauli District of Uttar Pradesh, India. Journal of Ethnopharmacology 121:324-329

Singh B, Borthakur SK, Phukan SJ (2014) A survey of ethnomedicinal plants utilized by the indigenous people of Garo hills with special reference to the Nokrek biosphere reserve (Meghalaya), India. Journal of Herbs, Spices and Medicinal Plants 20:1-30

Siva R (2007) Status of natural dyes and dyeyielding plants in India. Current Science 92:916-925
Subrahmanya PK (2012) Exploration and elucidation of traditional medicinal plants of erstwhile tulunadu and surrounding area of Kerala and Karnataka. PhD Thesis, Kannur University, Kannur, Kerala, India

Sutha S, Mohan VR, Kumaresan S, Murugan C, Athiperumalsami $T$ (2010) Ethnomedicinal plants used by the tribals of KalakadMundanthurai Tiger Reserve (KMTR), Western Ghats, Tamil Nadu for the treatment of rheumatism. Indian Journal of Traditional Knowledge 9:502-509

Tanaka R, Nakata T, Yamaguchi C, Wada SI, Yamada T, Tokuda H (2008) Potential antitumor-promoting activity of 3a-hydroxy-D: Afriedooleanan-2-one from the stem bark of Mallotus philippensis. Planta Medica 74:413416

Taylor RSL, Edel F, Manandhar NP, Towers GHN (1996a) Antimicrobial activities of southern Nepalese medicinal plants. Journal of Ethnopharmacology 50:97-102

Taylor RSL, Hudson JB, Manandhar NP, Towers GHN (1996b) Antiviral activities of medicinal plants of southern Nepal. Journal of Ethnopharmacology 53:97-104

Tripathi IP, Chaudhary P, Pandey P (2017) Mallotus philippensis: A Miracle Stick. World Journal of Pharmaceutical Research 6:678-687

Tshering S (1996) Natural Vegetable Dyes; Food, Fruit Species and Mushrooms; Gums and Waxes; and Incense. Non-Wood Forest Products of Bhutan. The Food and Agriculture Organization of the United Nations, Bangkok, Thailand, pp. 87-106

Turland N, Wiersema J, Barrie F, Greuter W, Hawksworth D, Herendeen P, Knapp S, Kusber W-H, Li D-Z, Marhold K, May T, McNeill J, Monro A, Prado J, Price M, Smith G (2018) International Code of Nomenclature for algae, fungi, and plants (Shenzhen Code) adopted by the Nineteenth International Botanical Congress Shenzhen, China, July 2017. Koeltz Botanical Books, Glashütten, Germany

Udayan PS, Harinarayanan MK, Tushar K V, Balachandran I (2008) Some common plants used by Kurichiar tribes of Tirunelli forest, Wayanad district, Kerala in medicine and other traditional uses. Indian Journal of Traditional Knowledge 7:250-255 
Uprety Y, Poudel RC, Asselin H, Boon E (2011) Plant biodiversity and ethnobotany inside the projected impact area of the Upper Seti Hydropower Project, Western Nepal. Environment, Development and Sustainability 13:463-492

Usmanghani K, Seed A, Alam M, Saeed A (1997) Indusyunic Medicine, Traditional Medicine of Herbal, Animal, and Mineral Origin in Pakistan. University of Karachi, Karachi, Pakistan

Verma S, Chauhan NS (2007) Indigenous medicinal plants knowledge of Kunihar forest division, district Solan. Indian Journal of Traditional Knowledge 6:494-497

Yesodharan K, Sujana KA (2007) Ethnomedicinal knowledge among Malamalasar tribe of Parambikulam wildlife sanctuary, Kerala. Indian Journal of Traditional Knowledge 6:481-485
Zabihullah Q, Rasheed A, Akhtar N (2006) Ethnobotanical survey of Kot Manzary Baba valley, Malakand Agency, Pakistan. Pakistan Journal of Plant Science 12:115-121

Zheng X long, Xing F wu (2009) Ethnobotanical study on medicinal plants around Mt.Yinggeling, Hainan Island, China. Journal of Ethnopharmacology 124:197-210

Zheng XL, Wei JH, Sun W, Li RT, Liu SB, Dai HF (2013) Ethnobotanical study on medicinal plants around Limu Mountains of Hainan Island, China. Journal of Ethnopharmacology 148:964-974
Received: 11 January 2020

Accepted: 14 May 2020

Published: 21 May 2020 


\section{ADDITIONAL FILE 1}

\section{List of selected studies for the present review}

1. Abbasi AM, Ajab Khan M, Ahmed M, Zafar M (2010a) Herbal medicines used to cure various ailments by the inhabitants of Abbottabad district, North West Frontier Province, Pakistan. Indian Journal of Traditional Knowledge 9:175-183

2. Abbasi AM, Khan MA, Ahmad M, Zafar M, Jahan S, Sultana S (2010b) Ethnopharmacological application of medicinal plants to cure skin diseases and in folk cosmetics among the tribal communities of North-West Frontier Province, Pakistan. Journal of Ethnopharmacology 128:322335

3. Abbasi AM, Khan SM, Ahmad M, Khan MA, Quave CL, Pieroni A (2013) Botanical ethnoveterinary therapies in three districts of the Lesser Himalayas of Pakistan. Journal of Ethnobiology and Ethnomedicine 9:84

4. Acharya R, Acharya KP (2010) Ethnobotanical Study of Medicinal Plants used by Tharu Community of Parroha VDC, Rupandehi District, Nepal. Scientific World 7:80-84

5. Ahmad SS, Mahmood F, Dogar Z, Iqbal Khan Z, Ahmad K, Sher M, Mustafa I, Elahi Valeem E (2009) Prioritization of medicinal plants of Margala Hills National Park, Islamabad on the basis of available information. Pakistan Journal of Botany 41:2105-2114

6. Ahmed E, Arshad M, Saboor A, Qureshi R, Mustafa G, Sadiq S, Chaudhari SK (2013) Ethnobotanical appraisal and medicinal use of plants in Patriata, New Murree, evidence from Pakistan. Journal of Ethnobiology and Ethnomedicine 9:13

7. Ahmed KMI, Bashar S, Tanny UT, Mandal BK, Islam E (2017) Ethnomedicinal formulations of a Garo tribal healer in Haluaghat, Mymensingh district, Bangladesh. Journal of Medicinal Plants Studies 5:219-223

8. Akhtar MS, Ahmad I (1992) Comparative efficacy of Mallotus philippinensis fruit (Kamala) or Nilzan ${ }^{\circledR}$ drug against gastrointestinal cestodes in Beetal goats. Small Ruminant Research 8:121128

9. Ayyanar M, Ignacimuthu S (2005) Traditional knowledge of Kani tribals in Kouthalai of Tirunelveli hills, Tamil Nadu, India. Journal of Ethnopharmacology 102:246-255

10. Aziz MA, Khan AH, Adnan M, Izatullah I (2017) Traditional uses of medicinal plants reported by the indigenous communities and local herbal practitioners of Bajaur Agency, Federally Administrated Tribal Areas, Pakistan. Journal of Ethnopharmacology 198:268-281

11. Barkatullah, Ibrar M, Rauf A, Ben Hadda T, Mubarak MS, Patel S (2015) Quantitative ethnobotanical survey of medicinal flora thriving in Malakand Pass Hills, Khyber Pakhtunkhwa, Pakistan. Journal of Ethnopharmacology 169:335-346

12. Bharati KA, Sharma BL (2010) Some ethnoveterinary plant records for Sikkim Himalaya. Indian Journal of Traditional Knowledge 9:344-346

13. Bharati KA, Sharma BL (2012) Plants used as ethnoveterinary medicines in Sikkim Himalayas. Ethnobotany Research and Applications 10:339-356

14. Bhatia H, Sharma YP, Manhas RK, Kumar K (2014) Ethnomedicinal plants used by the villagers of district Udhampur, J\&K, India. Journal of Ethnopharmacology 151:1005-1018

15. Biswas S (2012) Ethnobotanical studies of Malkangiri district Orissa including identification of a few potential species for modern drug development programme. Utkal University, Bhubaneswar, Odisha,

16. Chakraborty MK, Bhattacharjee A (2006) Some common ethnomedicinal uses for various diseases in Purulia district, West Bengal. Indian Journal of Traditional Knowledge 5:554-558 
17. Chander MP, Kartick C, Gangadhar J, Vijayachari P (2014) Ethno medicine and healthcare practices among Nicobarese of Car Nicobar - An indigenous tribe of Andaman and Nicobar Islands. Journal of Ethnopharmacology 158:18-24

18. Dahare D, Jain A (2010) Ethnobotanical Studies on Plant Resources of Tahsil Multai, District Betul, Madhya Pradesh, India. Ethnobotanical Leaflets 14:694-705

19. Das S, Sheeja TE, Mandal AB (2006) Ethnomedicinal uses of certain plants from Bay Islands. Indian Journal of Traditional Knowledge 5:207-211

20. Davis DK, Quraishi K, Sherman D, Sollod A, Stem C (1995) Ethnoveterinary medicine in Afghanistan: an overview of indigenous animal health care among Pashtun Koochi nomads. Journal of Arid Environments 31:483-500

21. Farooq Z, Iqbal Z, Mushtaq S, Muhammad G, Iqbal MZ, Arshad M (2008) Ethnoveterinary practices for the treatment of parasitic diseases in livestock in Cholistan desert (Pakistan). Journal of Ethnopharmacology 118:213-219

22. Ganesan S, Ponnuchamy M, Kesavan L, Selvaraj A (2009) Floristic composition and practices on the selected sacred groves of Pallapatty village (Reserved forest), Tamil Nadu. Indian Journal of Traditional Knowledge 8:154-162

23. Ghimire K, Bastakoti RR (2009) Ethnomedicinal knowledge and healthcare practices among the Tharus of Nawalparasi district in central Nepal. Forest Ecology and Management 257:20662072

24. Goraya K, Iqbal Z, Sajid MS, Muhammad G, Ain Q ul, Saleem M (2013) Diversity of flora used for the cure of equine diseases in selected peri-urban areas of Punjab, Pakistan. Journal of Ethnobiology and Ethnomedicine 9:70

25. Gupta AG (2015) Ethnobotanical studies of mount abu region in sirohi district Rajasthan. University of Rajasthan, Jaipur, Rajasthan,

26. Gupta VK, Kaushik A, Chauhan DS, Ahirwar RK, Sharma S, Bisht D (2018) Anti-mycobacterial activity of some medicinal plants used traditionally by tribes from Madhya Pradesh, India for treating tuberculosis related symptoms. Journal of Ethnopharmacology 227:113-120

27. Hamayun M, Khan A, Khan MA (2005) Common Medicinal Folk Recipes of District Buner, NWFP, Pakistan. Ethnobotanical Leaflets 2005:45

28. Hussain A, Khan MN, Iqbal Z, Sajid MS (2008) An account of the botanical anthelmintics used in traditional veterinary practices in Sahiwal district of Punjab, Pakistan. Journal of Ethnopharmacology 119:185-190

29. Jabbar A, Raza MA, Iqbal Z, Khan MN (2006) An inventory of the ethnobotanicals used as anthelmintics in the southern Punjab (Pakistan). Journal of Ethnopharmacology 108:152-154

30. Jagtap SD, Deokule SS, Bhosle S V. (2006) Some unique ethnomedicinal uses of plants used by the Korku tribe of Amravati district of Maharashtra, India. Journal of Ethnopharmacology 107:463-469

31. Jain SP, Puri HS (1984) Ethnomedicinal plants of Jaunsar-Bawar hills, Uttar Pradesh, India. Journal of Ethnopharmacology 12:213-22

32. Joshi AR, Joshi K (2007) Ethnomedicinal Plants Used Against Skin Diseases in Some Villages of Kali Gandaki, Bagmati and Tadi Likhu Watersheds of Nepal. Ethnobotanical Leaflets 11:235-246

33. Kamble SY, Patil SR, Sawant PS, Sawant S, Pawar SG, Singh EA (2010) Studies on plants used in traditional medicine by Bhilla tribe of Maharashtra. Indian Journal of Traditional Knowledge 9:591-598

34. Khan S, Chaghtai S (1982) Ethnobotanical study of some plants used for curing skin afflictions. Ancient Science of Life 1:236-238

35. Khare CP (2007) Indian Medicinal Plants- An Illustrated Dictionary. Springer, New York 
36. Khuankaew S, Srithi K, Tiansawat P, Jampeetong A, Inta A, Wangpakapattanawong P (2014) Ethnobotanical study of medicinal plants used by Tai Yai in Northern Thailand. Journal of Ethnopharmacology 151:829-838

37. Kirtikar KR, Basu BD (1935) Indian Medicinal Plants. 2 ed. Lalit Mohan Basu, Allahabad, India

38. Kosalge SB, Fursule RA (2009) Investigation of ethnomedicinal claims of some plants used by tribals of Satpuda Hills in India. Journal of Ethnopharmacology 121:456-461

39. Kumar GMP, Nagayya S (2017) Utilization of ethno-veterinary medicinal plants in Hassan district of Karnataka, India. International Journal of Pharmacy and Pharmaceutical Sciences 9:107

40. Kumar R, Bharati KA (2014) Ethnomedicines of Tharu tribes of Dudhwa National Park, India. Ethnobotany Research and Applications 12:001-013

41. Mahato RB, Chaudhary RP (2005) Ethnomedicinal study and antibacterial activities of selected plants of Palpa district, Nepal. Scientific World 3:26-31

42. Malik ZA, Bhat JA, Ballabha R, Bussmann RW, Bhatt AB (2015) Ethnomedicinal plants traditionally used in health care practices by inhabitants of Western Himalaya. Journal of Ethnopharmacology 172:133-144

43. Manandhar NP (1998) Native phytotherapy among the Raute tribes of Dadeldhura district, Nepal. Journal of Ethnopharmacology 60:199-206

44. Maruthupandian A, Mohan VR, Kottaimuthu R (2011) Ethnomedicinal plants used for the treatment of diabetes and jaundice by Palliyar tribals in sirumalai hills, Western Ghats, Tamil Nadu, India. Indian Journal of Natural Products and Resources 2:493-497

45. Nayak S, Behera SK, Misra MK (2004) Ethno-medico-botanical survey of Kalahandi district of Orissa. Indian Journal of Traditional Knowledge 3:72-79

46. Panda SK (2014) Ethno-medicinal uses and screening of plants for antibacterial activity from Similipal Biosphere Reserve, Odisha, India. Journal of Ethnopharmacology 151:158-175

47. Panda SK, Das R, Leyssen P, Neyts J, Luyten W (2018) Assessing medicinal plants traditionally used in the Chirang Reserve Forest, Northeast India for antimicrobial activity. Journal of Ethnopharmacology 225:220-233

48. Panthi MP, Singh AG (2013) Ethnobotany of Arghakhanchi District, Nepal: Plants used in dermatological and cosmetic disorders. International Journal of Applied Sciences and Biotechnology 1:27-32

49. Patil M V, Patil DA (2004) Plants used in reproductive ailments by tribals of Nasik district (Maharashtra). Ancient Science of Life 23:37-41

50. Pattanaik C, Reddy CS, Dhal NK, Das R (2006) Some Phytotherapeutic Claims by Tribals of Rayagada District, Orissa, India. Ethnobotanical Leaflets 10:189-197

51. Poonam K, Singh GS (2009) Ethnobotanical study of medicinal plants used by the Taungya community in Terai Arc Landscape, India. Journal of Ethnopharmacology 123:167-176

52. Rao PK, Hasan SS, Bhellum BL, Manhas RK (2015) Ethnomedicinal plants of Kathua district, J\&K, India. Journal of Ethnopharmacology 171:12-27

53. Rashid S, Ahmad M, Zafar M, Sultana S, Ayub M, Khan MA, Yaseen G (2015) Ethnobotanical survey of medicinally important shrubs and trees of Himalayan region of Azad Jammu and Kashmir, Pakistan. Journal of Ethnopharmacology 166:340-351

54. Reddy RV (1995) Ethnobotanical and phytochemical studies on medicinal plant resources of Cuddapah district AP India. Sri Krishnadevaraya University, Anantapur, Andhra Pradesh, India

55. Reddy SR (1996) Floristic and ethnobotanical studies on Lankamala hills Cuddapah district AP. Sri Krishnadevaraya University, Anantapur, Andhra Pradesh, India

56. Saqib Z, Mahmood A, Naseem Malik R, Mahmood A, Hussian Syed J, Ahmad T (2014) Indigenous knowledge of medicinal plants in Kotli Sattian, Rawalpindi district, Pakistan. Journal of Ethnopharmacology 151:820-828 
57. Seethapathy GS, Ravikumar K, Paulsen BS, de Boer HJ, Wangensteen H (2018) Ethnobotany of dioecious species: Traditional knowledge on dioecious plants in India. Journal of Ethnopharmacology 221:56-64

58. Shanmugam S, Gayathri N, Sakthivel B, Ramar S, Rajendran K (2009) Plants used as Medicine by Paliyar Tribes of Shenbagathope in Virudhunagar District of Tamilnadu, India. Ethnobotanical Leaflets 13:370-378

59. Sharma J, Gairola S, Gaur RD, Painuli RM (2012a) The treatment of jaundice with medicinal plants in indigenous communities of the Sub-Himalayan region of Uttarakhand, India. Journal of Ethnopharmacology 143:262-291

60. Sharma J, Gairola S, Sharma YP, Gaur RD (2014) Ethnomedicinal plants used to treat skin diseases by Tharu community of district Udham Singh Nagar, Uttarakhand, India. Journal of Ethnopharmacology 158:140-206

61. Sharma J, Gaur RD, Gairola S, Painuli RM, Siddiqi TO (2013) Traditional herbal medicines used for the treatment of skin disorders by the Gujjar tribe of Sub-Himalayan tract, Uttarakhand. Indian Journal of Traditional Knowledge 12:736-746

62. Sharma J, Painuli RM, Gaur RD (2010) Plants used by the rural communities of district Shahjahanpur, Uttar Pradesh. Indian Journal of Traditional Knowledge 9:798-803

63. Sharma R, Manhas RK (2015) Ethnoveterinary plants for the treatment of camels in Shiwalik regions of Kathua district of Jammu \& Kashmir, India. Journal of Ethnopharmacology 169:170175

64. Sharma R, Manhas RK, Magotra R (2012b) Ethnoveterinary remedies of diseases among milk yielding animals in Kathua, Jammu and Kashmir, India. Journal of Ethnopharmacology 141:265-272

65. Sher Z, Khan Z ud din, Hussain F (2011) Ethnobotanical studies of some plants of Chagharzai valley, district Buner, Pakistan. Pakistan Journal of Botany 43:1445-1452

66. Shil S, Choudhury MD (2009) Indigenous Knowledge on Healthcare Practices by the Reang Tribe of Dhalai District of Tripura, North East India. Ethnobotanical Leaflets 13:775-790

67. Shil S, Dutta Choudhury M, Das S (2014) Indigenous knowledge of medicinal plants used by the Reang tribe of Tripura state of India. Journal of Ethnopharmacology 152:135-141

68. Shukla AN, Srivastava S, Rawat AKS (2010) An ethnobotanical study of medicinal plants of Rewa district, Madhya Pradesh. Indian Journal of Traditional Knowledge 9:191-202

69. Sierra SEC, Van Welzen PC, Slik JWF (2005) A taxonomic revision of mallotus section philippinenses (former section Rottlera - Euphorbiaceae) in Malesia and Thailand. Blumea: Journal of Plant Taxonomy and Plant Geography 50:221-248

70. Singh A, Singh PK (2009) An ethnobotanical study of medicinal plants in Chandauli District of Uttar Pradesh, India. Journal of Ethnopharmacology 121:324-329

71. Singh B, Borthakur SK, Phukan SJ (2014) A survey of ethnomedicinal plants utilized by the indigenous people of Garo hills with special reference to the nokrek biosphere reserve (Meghalaya), India. Journal of Herbs, Spices and Medicinal Plants 20:1-30

72. Siva R (2007) Status of natural dyes and dye-yielding plants in India. Current Science 92:916925

73. Subrahmanya PK (2012) Exploration and elucidation of traditional medicinal plants of erstwhile Tulunadu and surrounding area of Kerala and Karnataka. Kannur University, Kannur, Kerala, India

74. Sutha S, Mohan VR, Kumaresan S, Murugan C, Athiperumalsami T (2010) Ethnomedicinal plants used by the tribals of Kalakad-Mundanthurai Tiger Reserve (KMTR), Western Ghats, Tamil Nadu for the treatment of rheumatism. Indian Journal of Traditional Knowledge 9:502-509

75. Taylor RSL, Edel F, Manandhar NP, Towers GHN (1996a) Antimicrobial activities of southern Nepalese medicinal plants. Journal of Ethnopharmacology 50:97-102 
76. Taylor RSL, Hudson JB, Manandhar NP, Towers GHN (1996b) Antiviral activities of medicinal plants of southern Nepal. Journal of Ethnopharmacology 53:97-104

77. Udayan PS, Harinarayanan MK, Tushar K V, Balachandran I (2008) Some common plants used by Kurichiar tribes of Tirunelli forest, Wayanad district, Kerala in medicine and other traditional uses. Indian Journal of Traditional Knowledge 7:250-255

78. Uprety Y, Poudel RC, Asselin H, Boon E (2011) Plant biodiversity and ethnobotany inside the projected impact area of the Upper Seti Hydropower Project, Western Nepal. Environment, Development and Sustainability 13:463-492

79. Usmanghani K, Seed A, Alam M, Saeed A (1997) Indusyunic Medicine, Traditional Medicine of Herbal, Animal, and Mineral Origin in Pakistan. University of Karachi, Karachi, Pakistan

80. Verma S, Chauhan NS (2007) Indigenous medicinal plants knowledge of Kunihar forest division, district Solan. Indian Journal of Traditional Knowledge 6:494-497

81. Yesodharan K, Sujana KA (2007) Ethnomedicinal knowledge among Malamalasar tribe of Parambikulam wildlife sanctuary, Kerala. Indian Journal of Traditional Knowledge 6:481-485

82. Zheng $X$ long, Xing $F$ wu (2009) Ethnobotanical study on medicinal plants around Mt.Yinggeling, Hainan Island, China. Journal of Ethnopharmacology 124:197-210

83. Zheng XL, Wei JH, Sun W, Li RT, Liu SB, Dai HF (2013) Ethnobotanical study on medicinal plants around Limu Mountains of Hainan Island, China. Journal of Ethnopharmacology 148:964974 


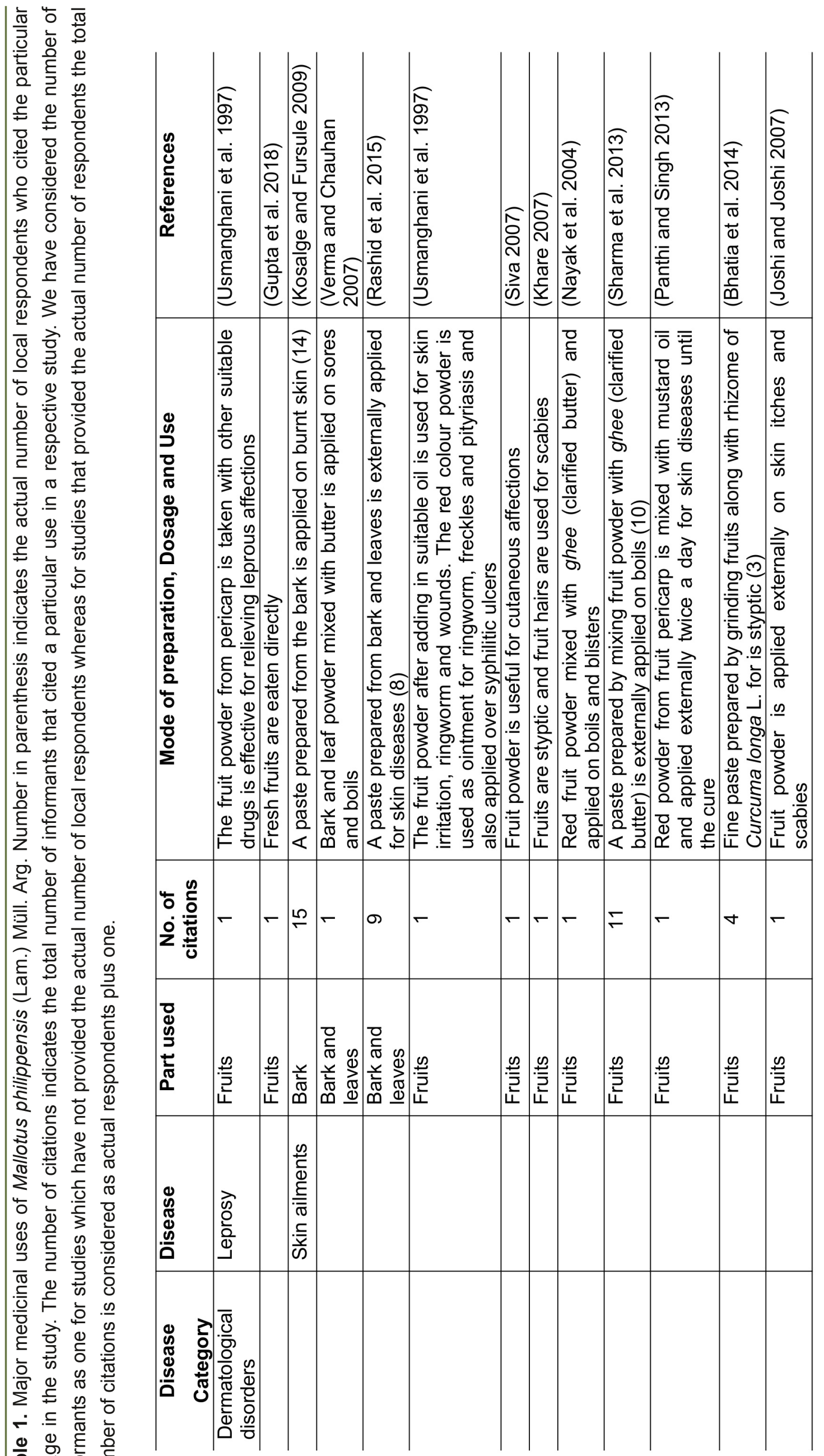




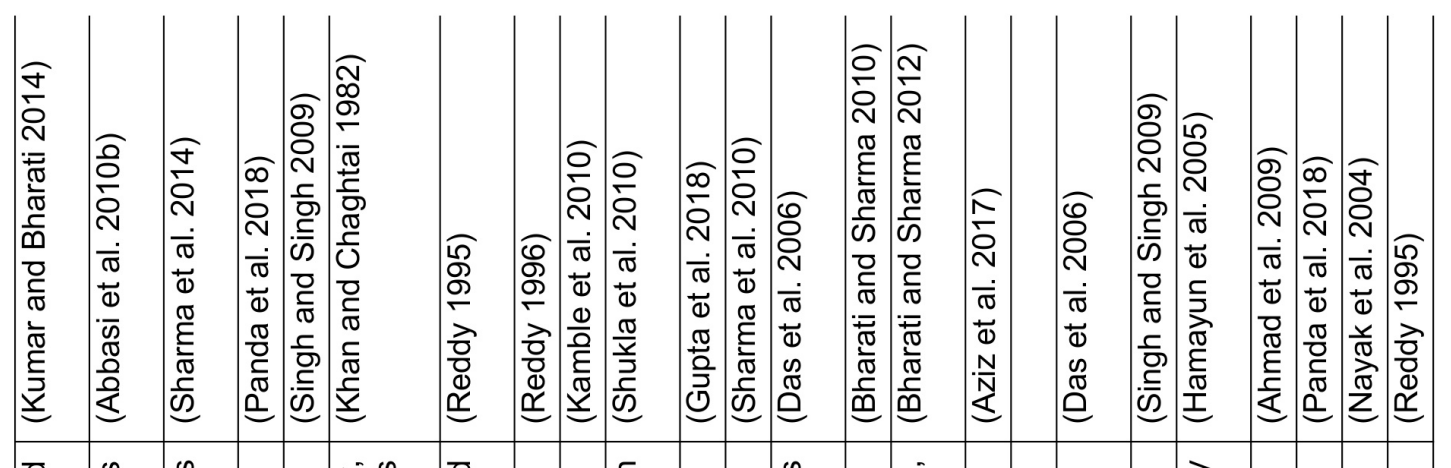




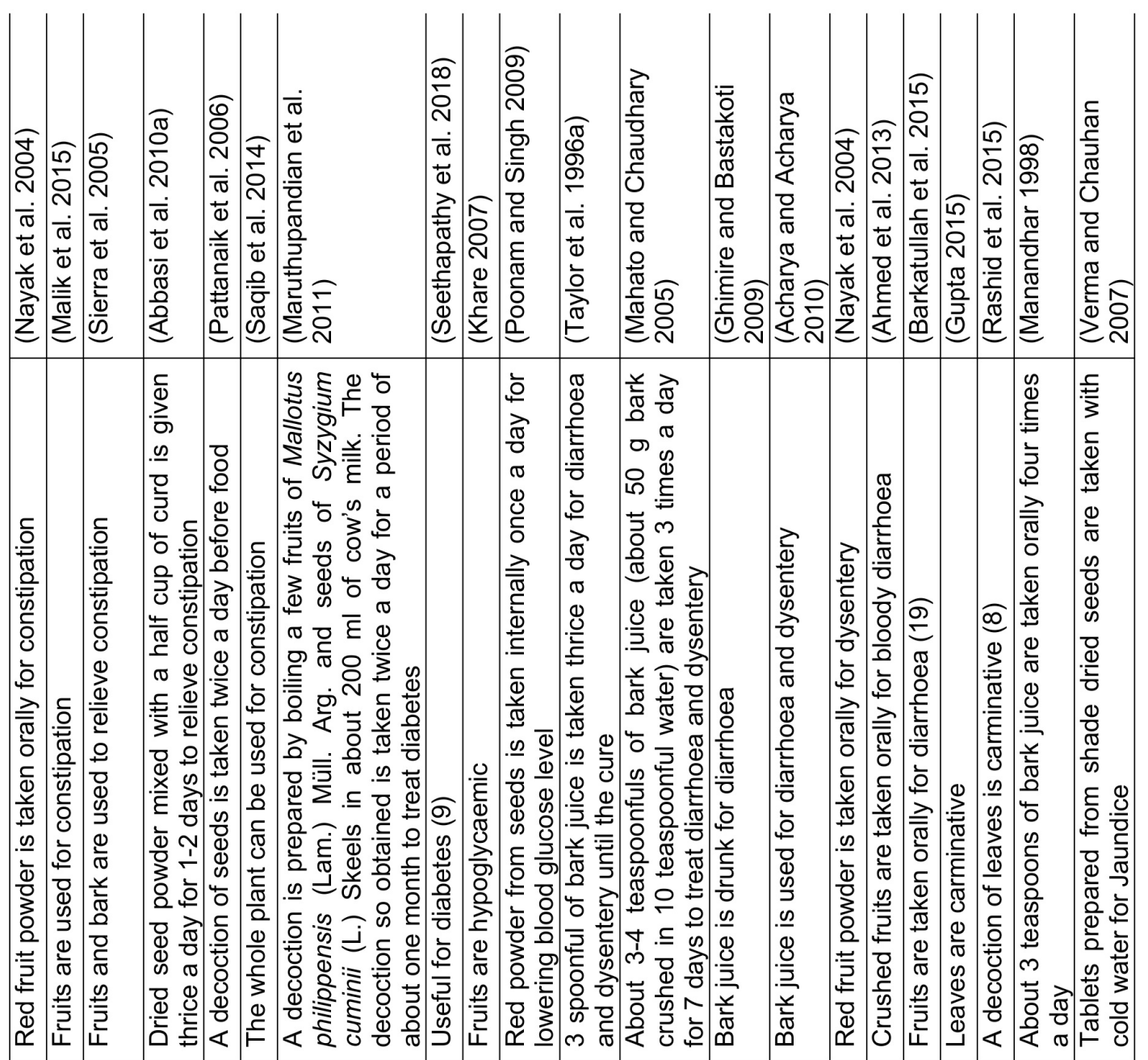




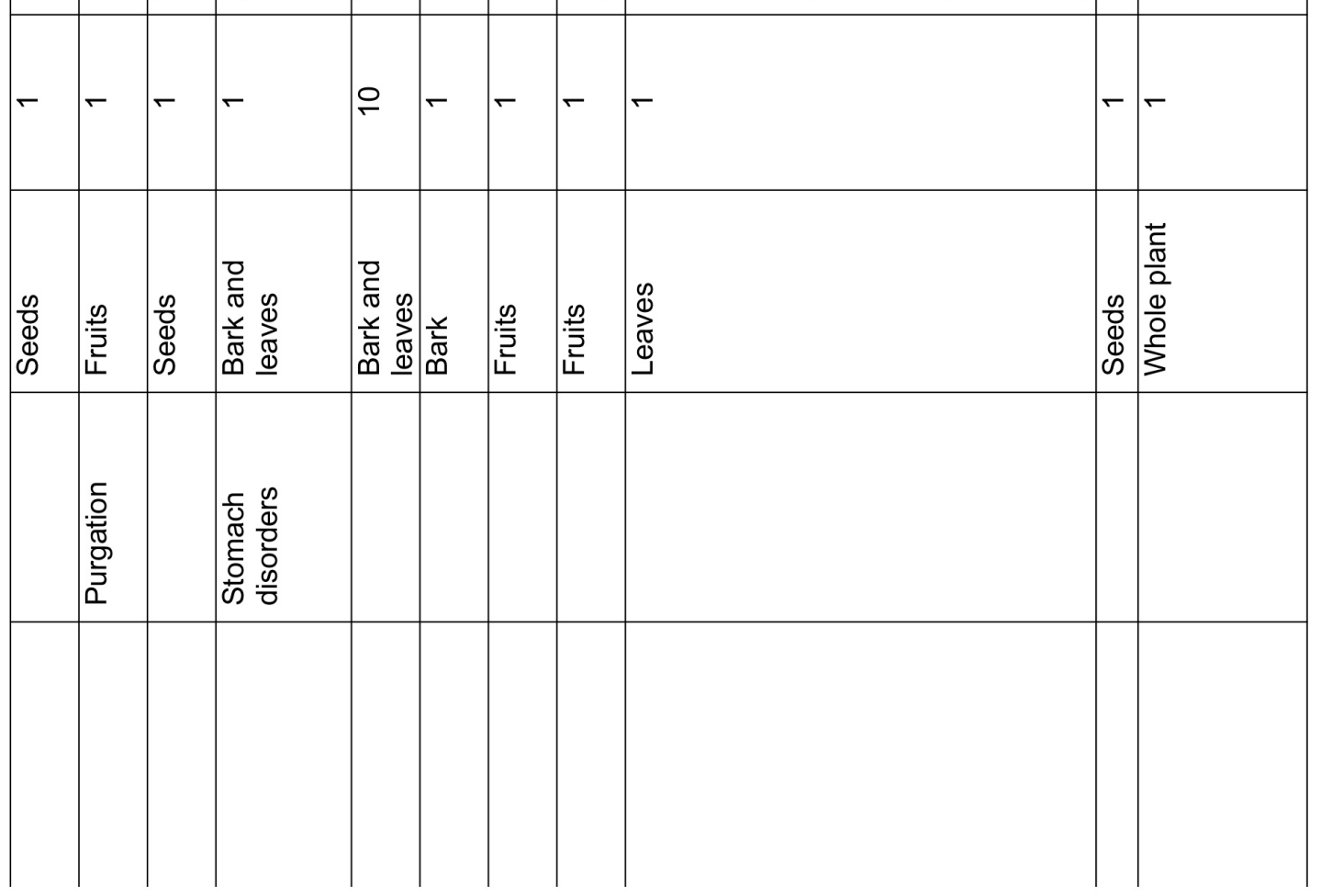




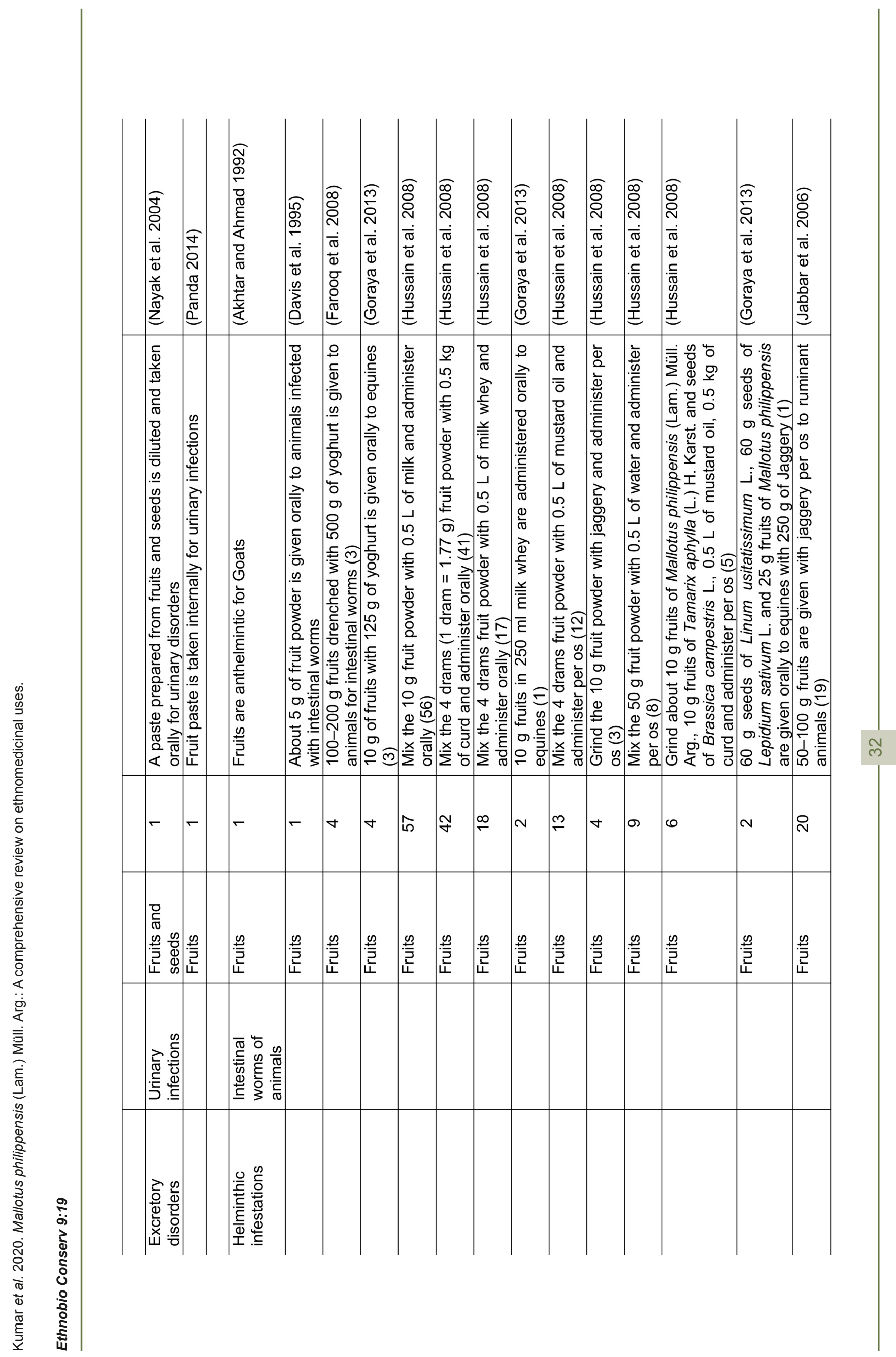




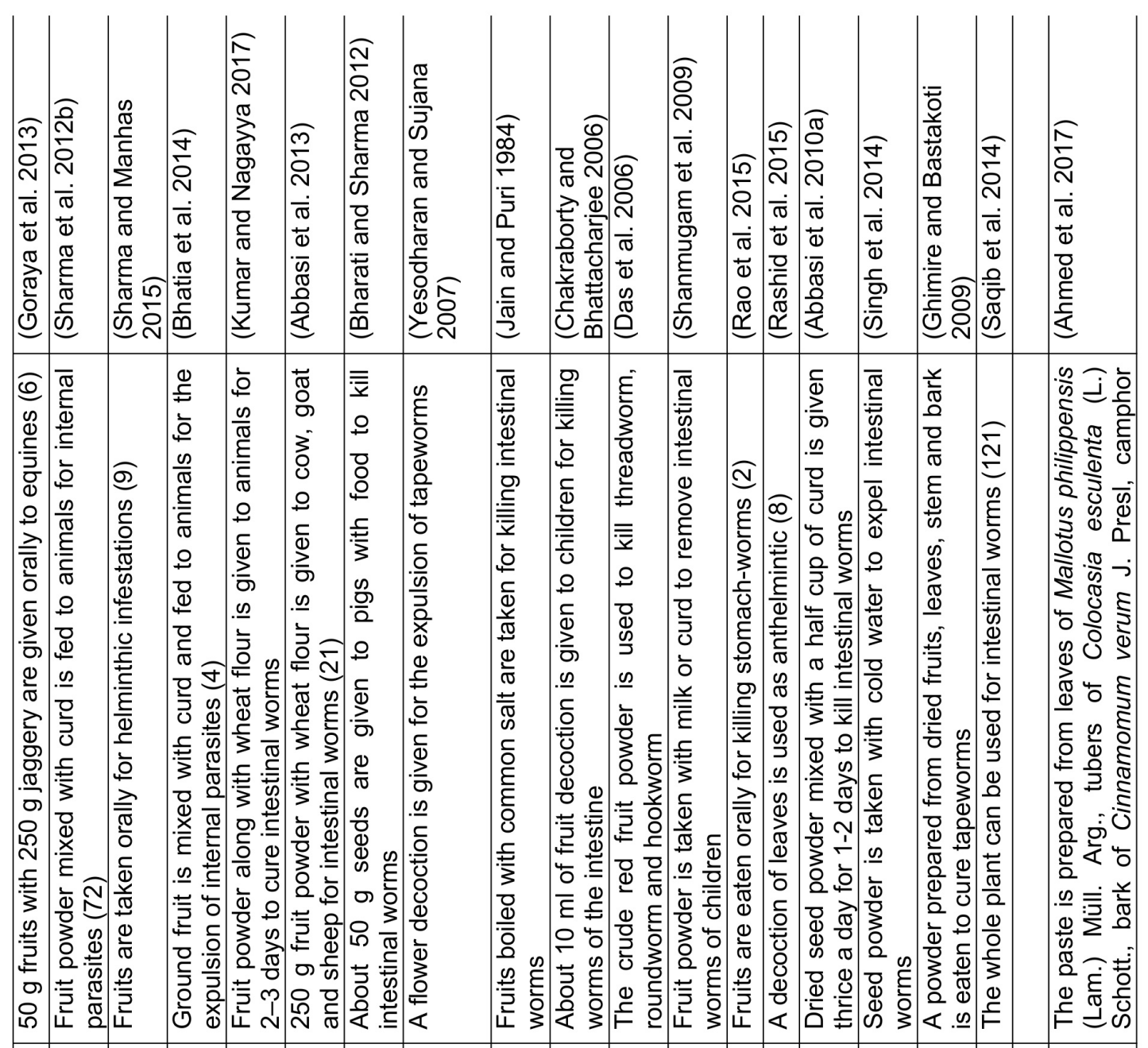

ก $\frac{1}{5}$ ก

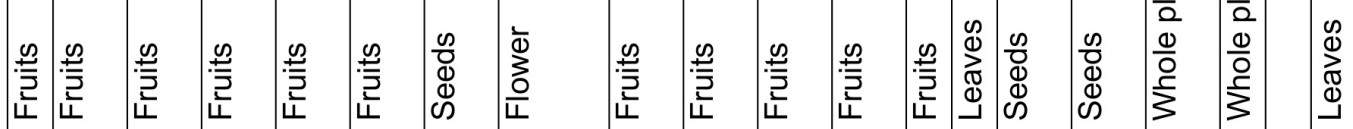




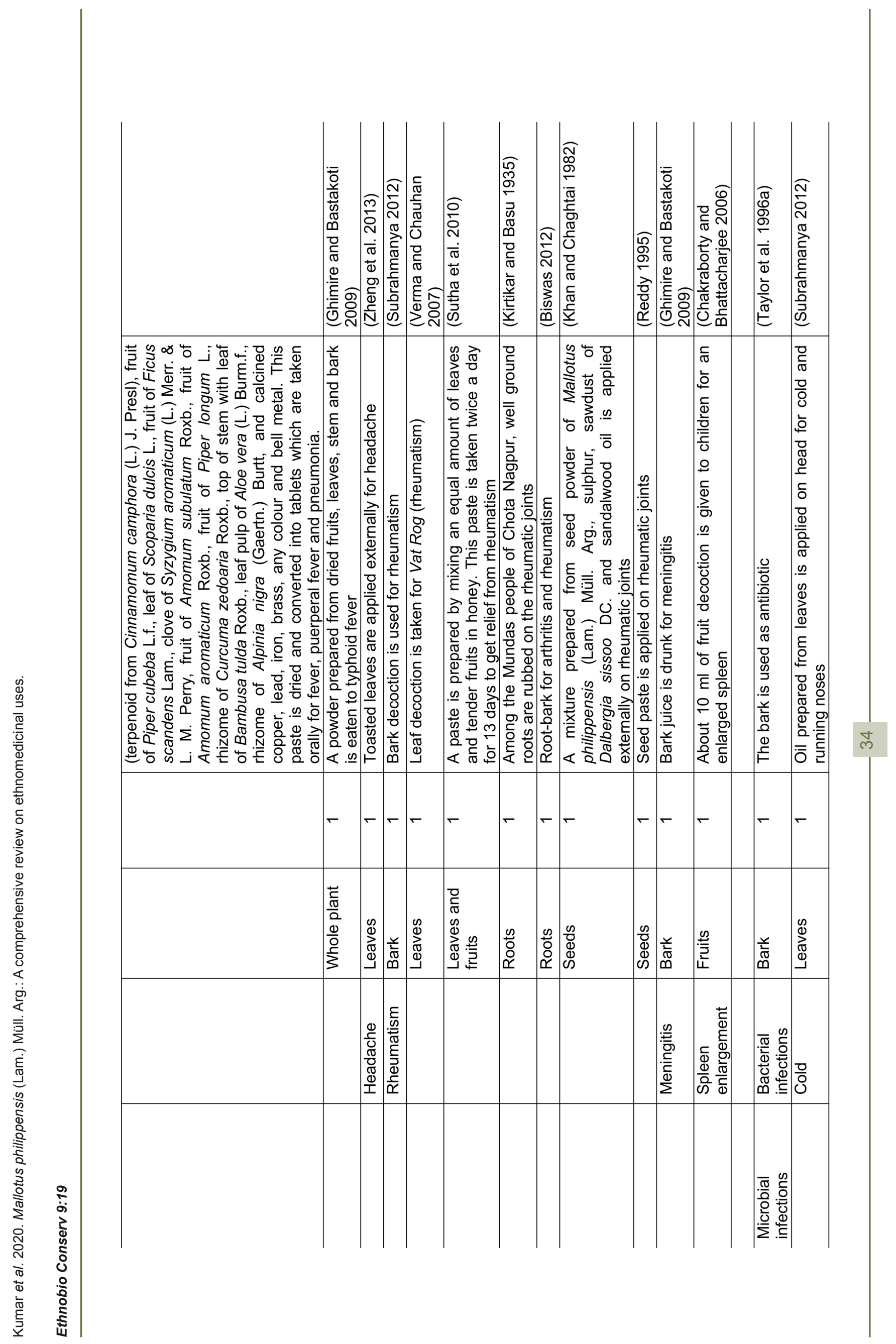




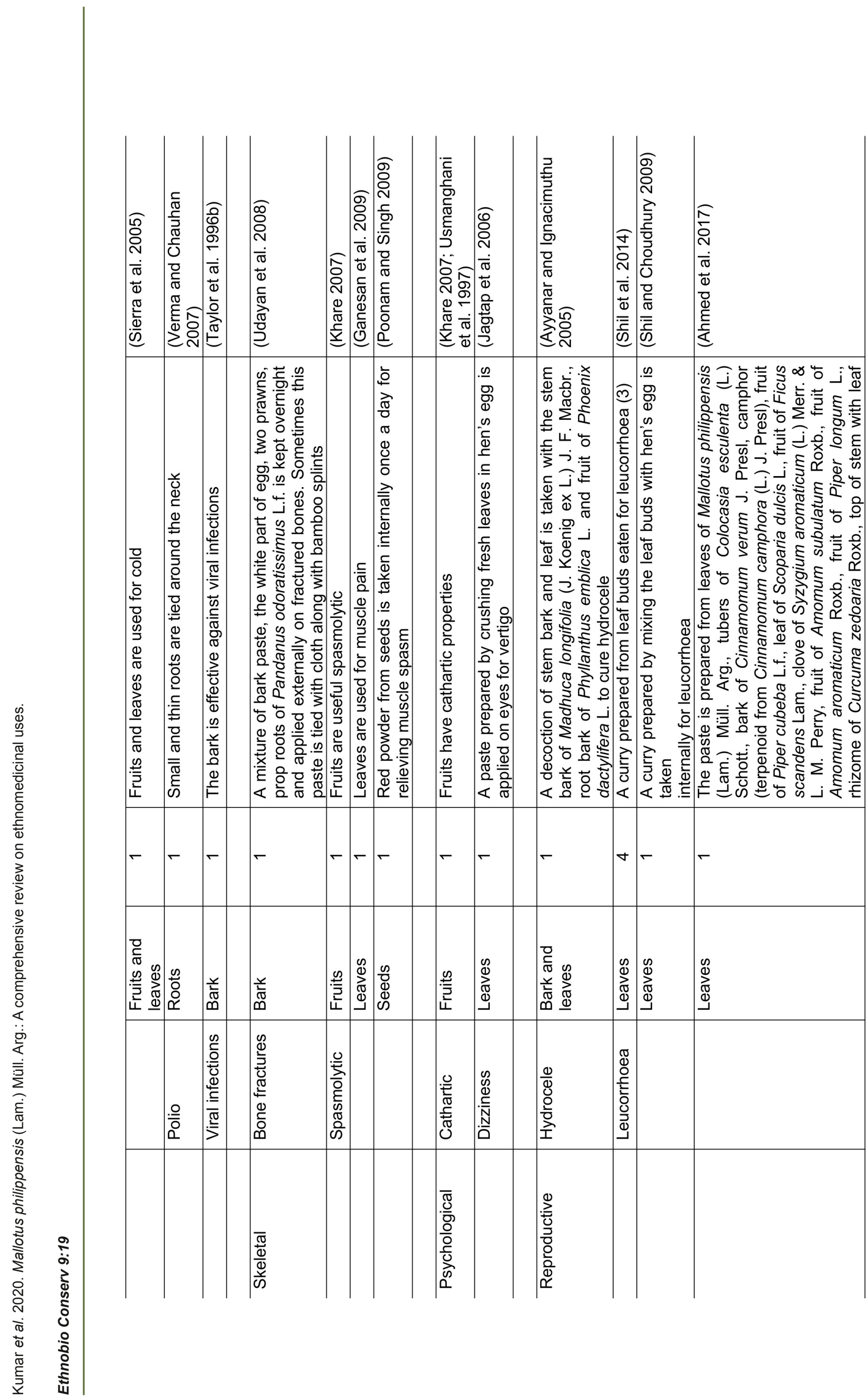

$\stackrel{m}{m}$ 







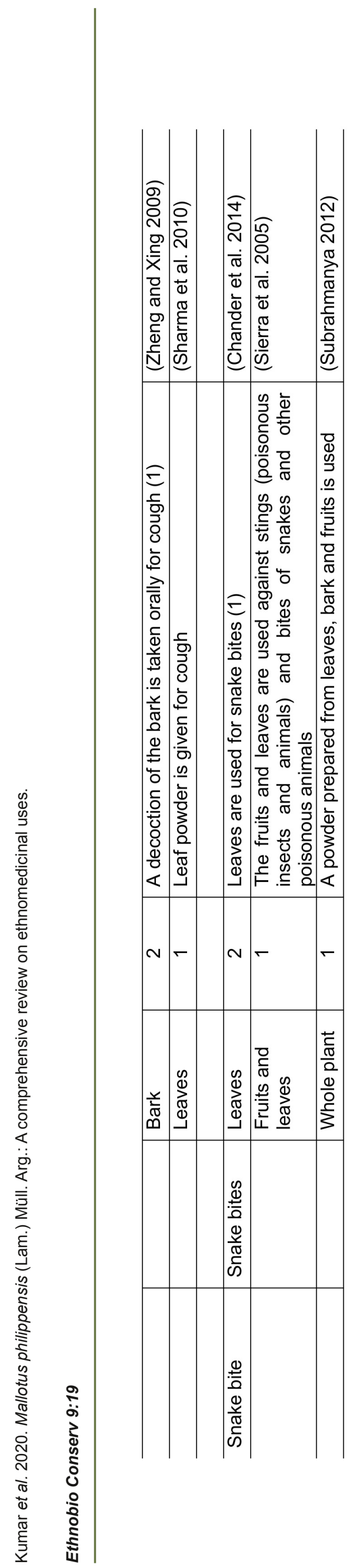




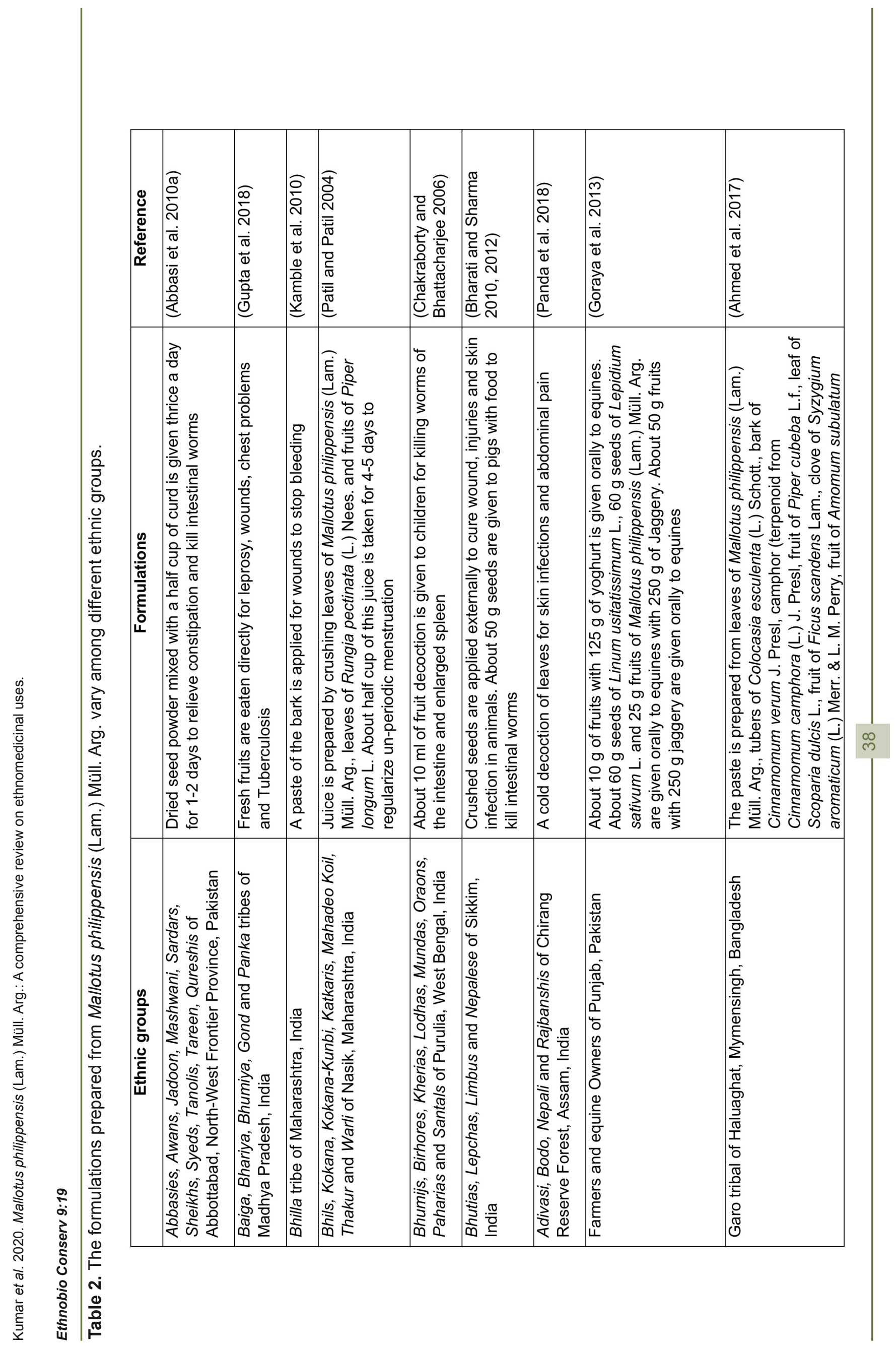




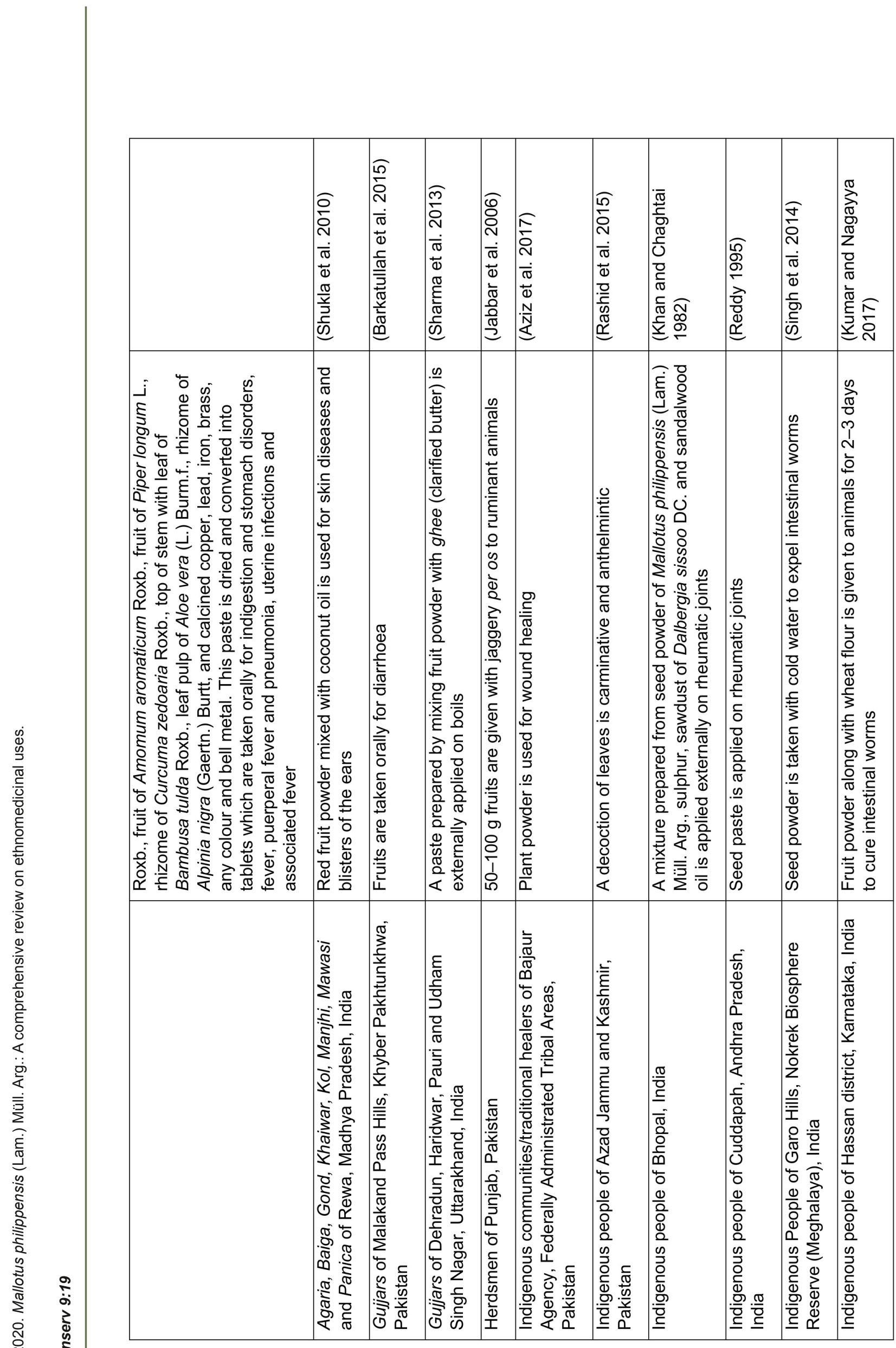




\begin{tabular}{|c|c|c|c|c|c|c|c|c|c|c|c|c|}
\hline 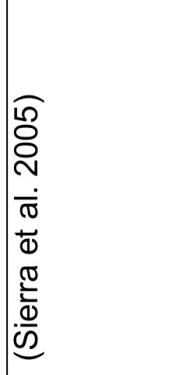 & 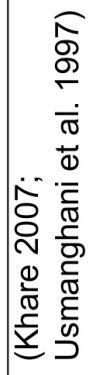 & 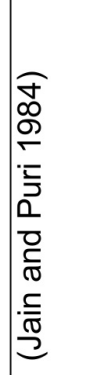 & 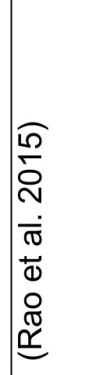 & 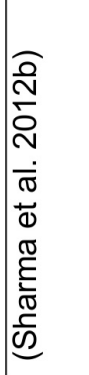 & 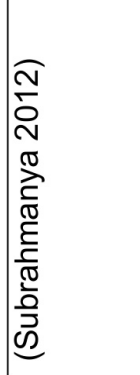 & 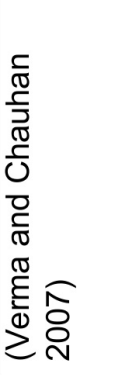 & 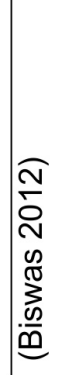 & 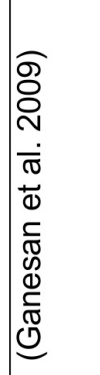 & 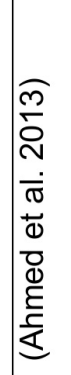 & 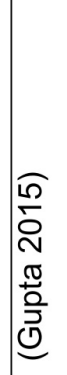 & 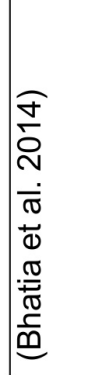 & 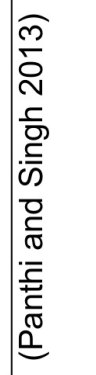 \\
\hline 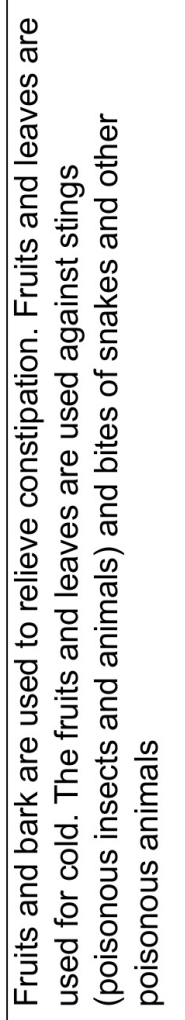 & 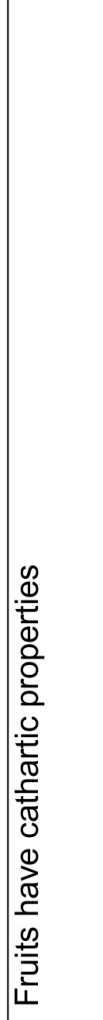 & 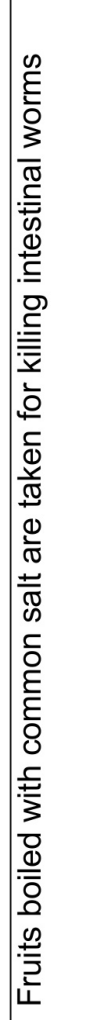 & 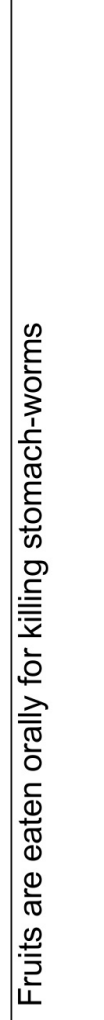 & 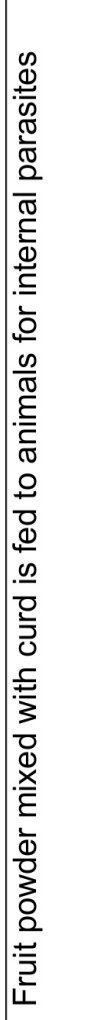 & 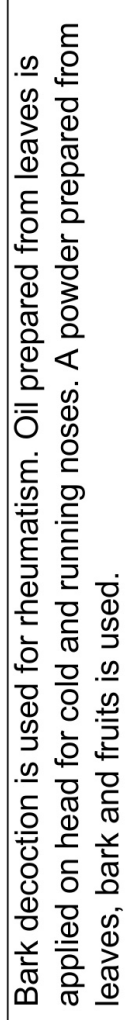 & 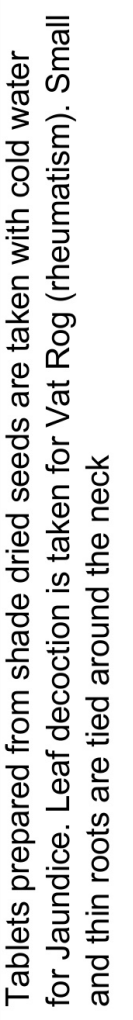 & 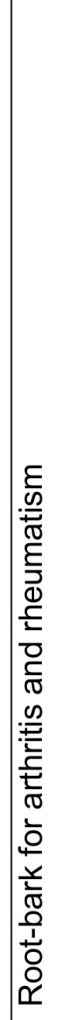 & 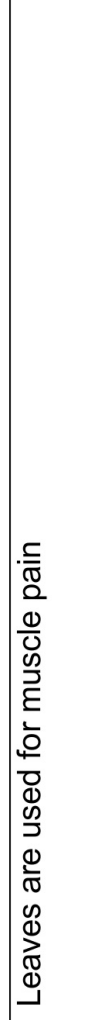 & 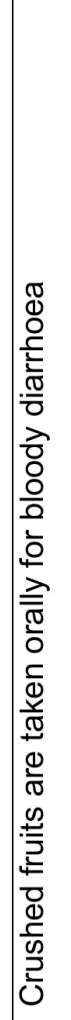 & 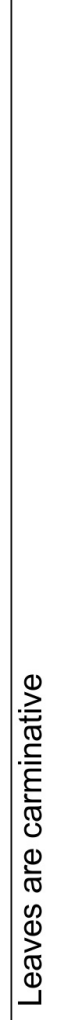 & 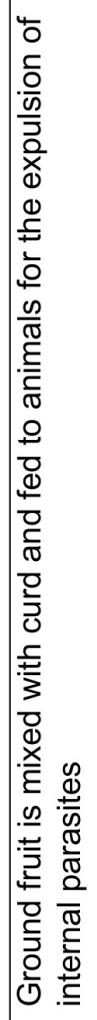 & 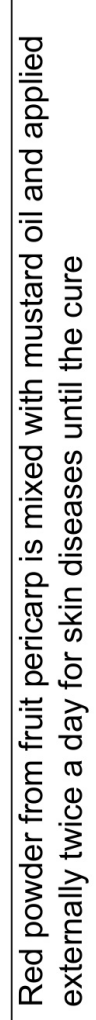 \\
\hline 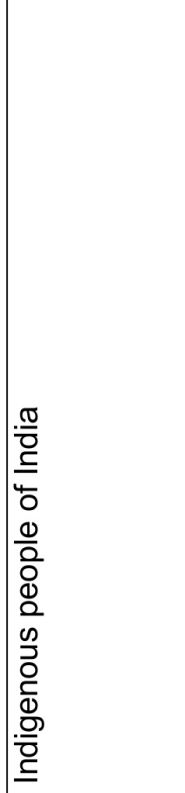 & 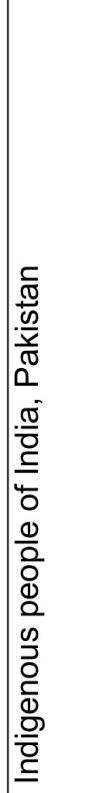 & 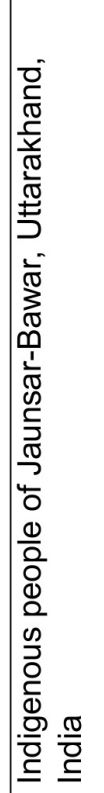 & 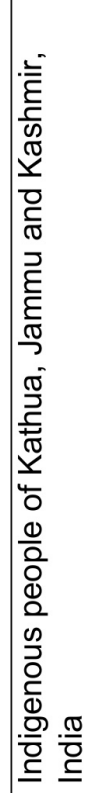 & 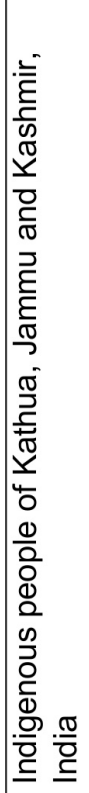 & 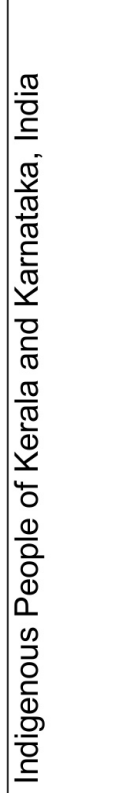 & 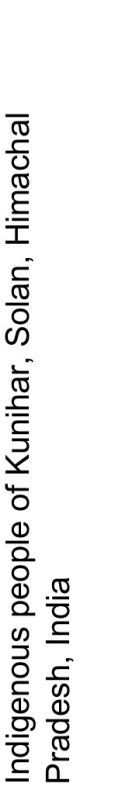 & 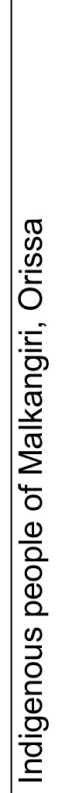 & 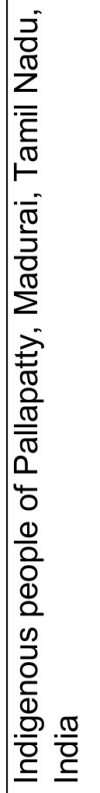 & 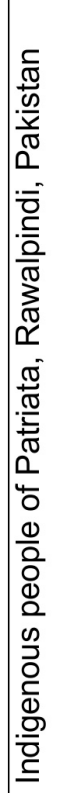 & 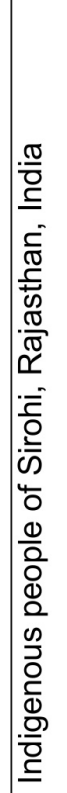 & 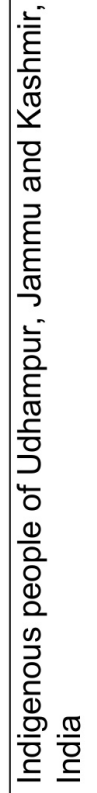 & 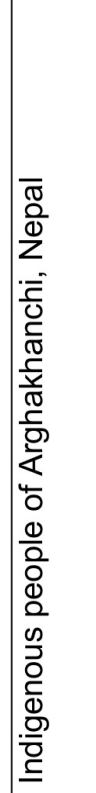 \\
\hline
\end{tabular}




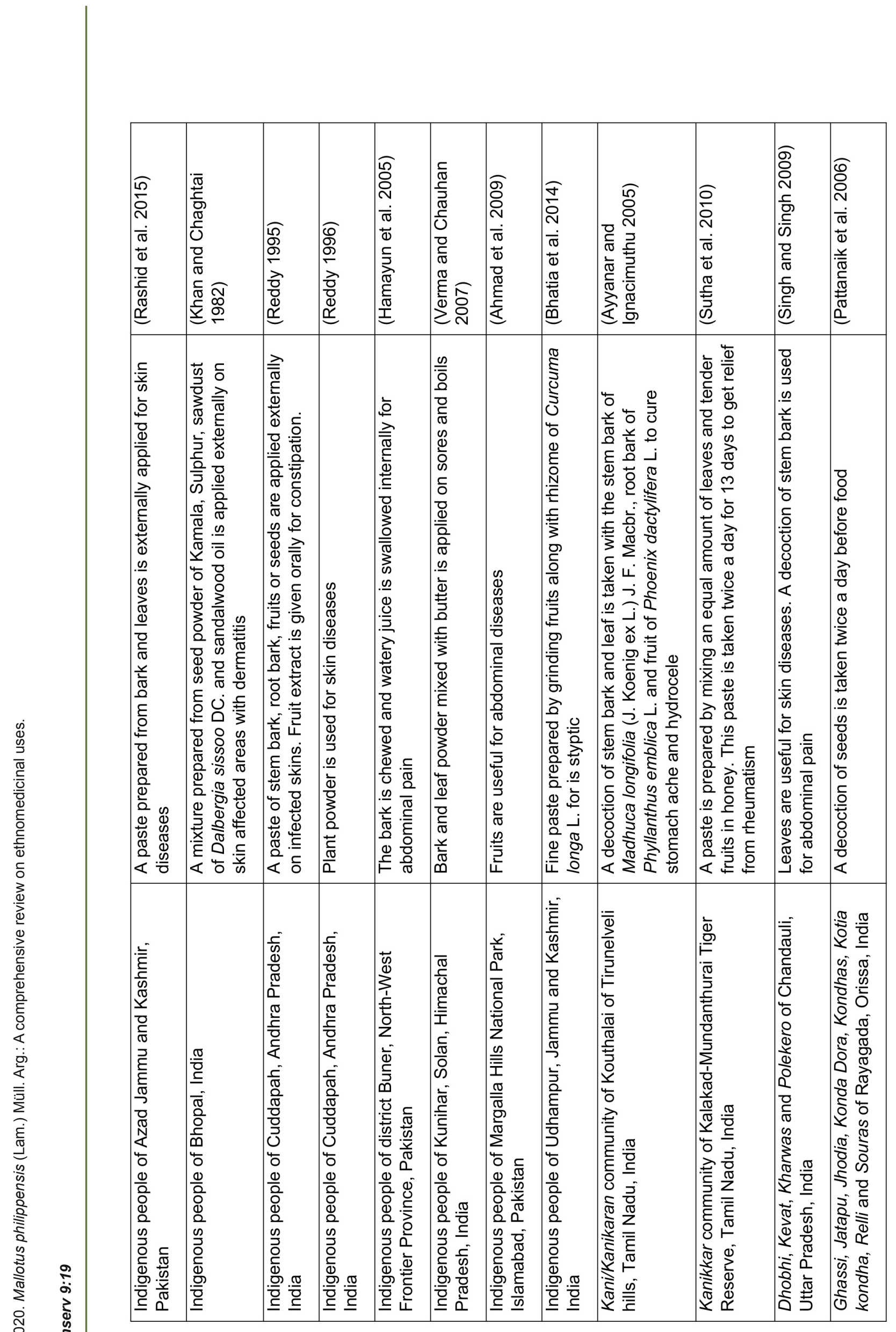




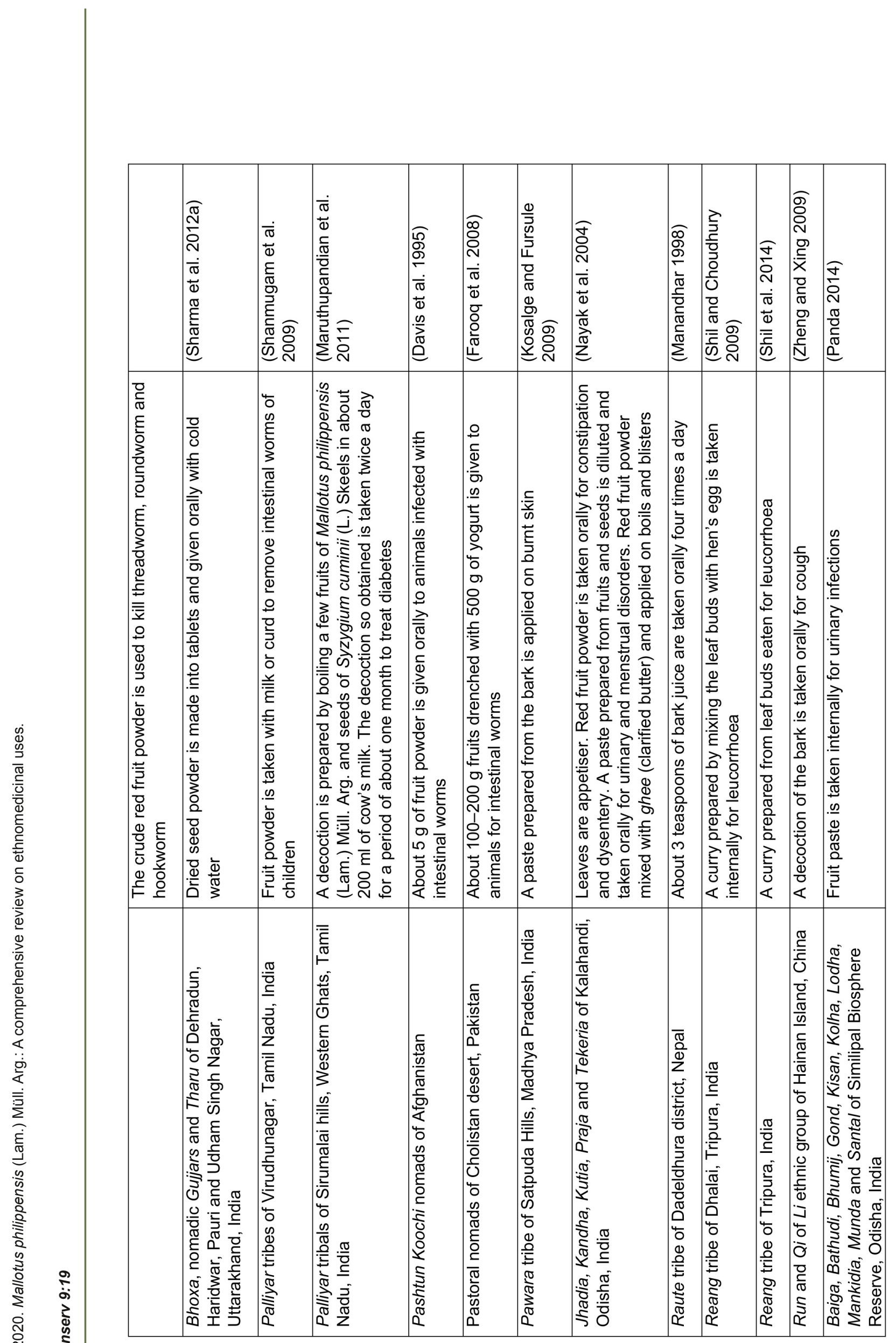




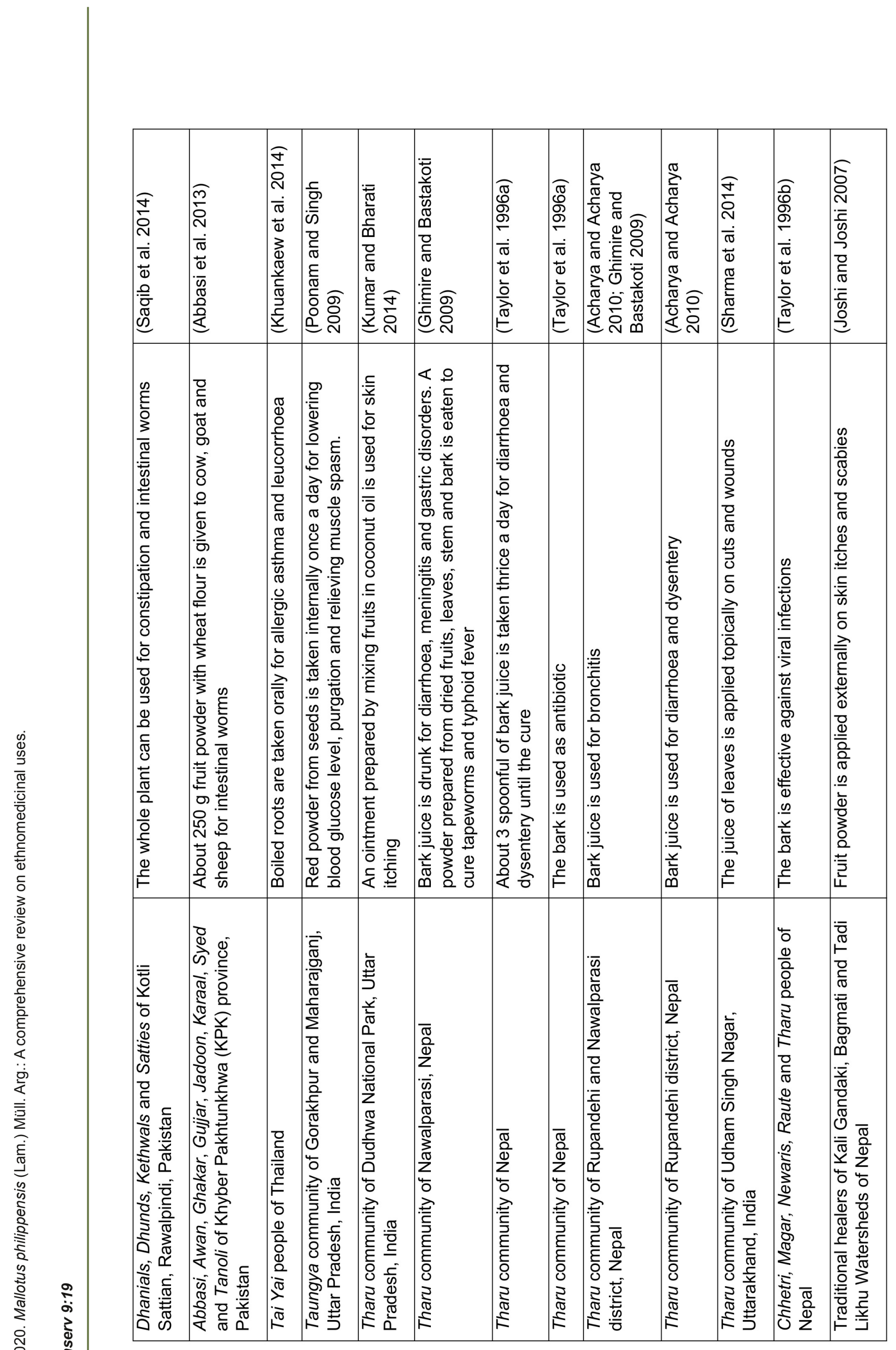




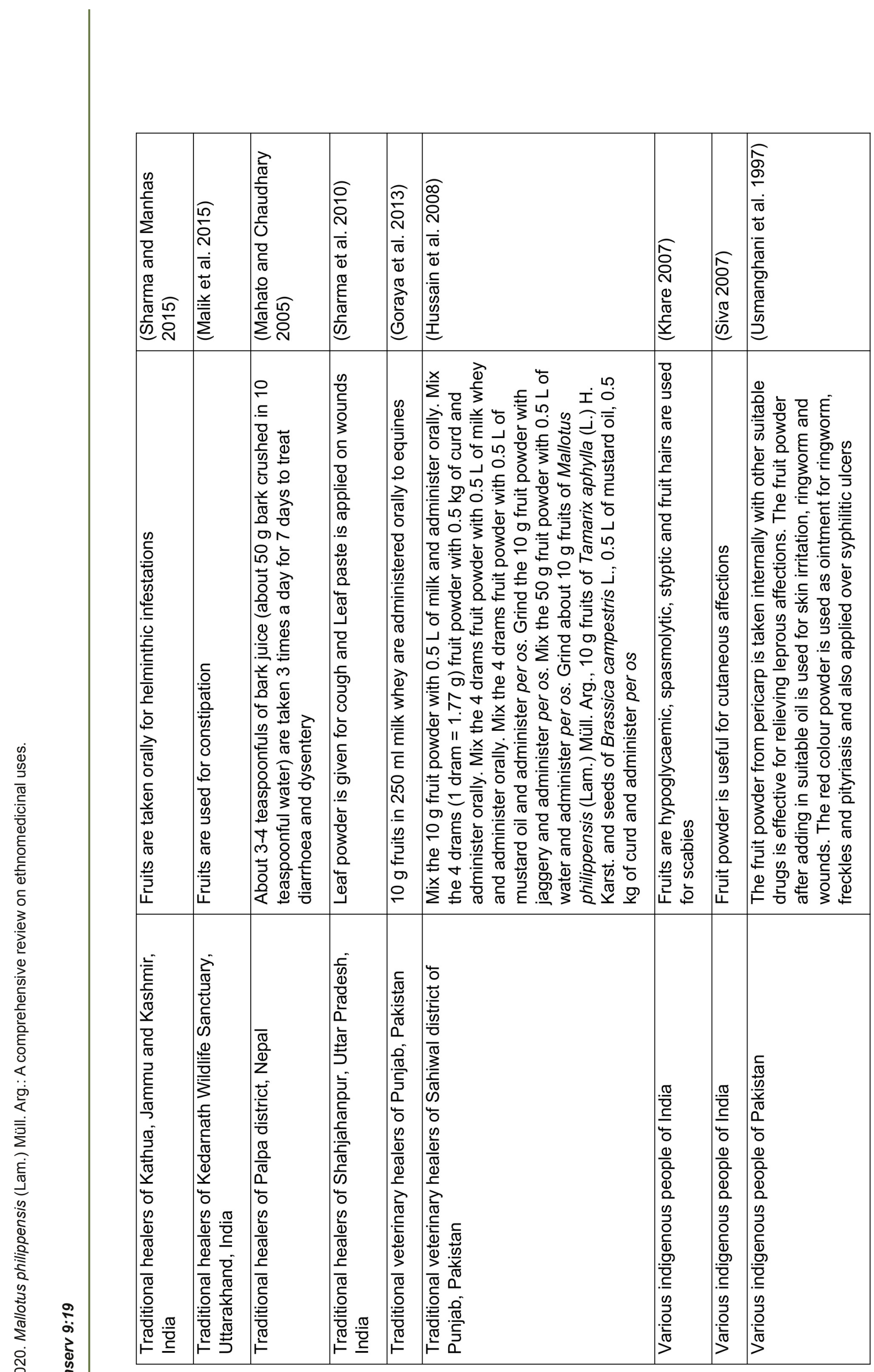

